\title{
Adsorption efficiency, thermodynamics and kinetics of Schiff base-modified nanoparticles for removal of heavy metals
}

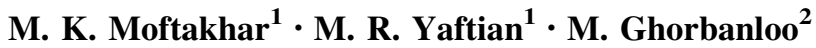

Received: 10 January 2015/Revised: 18 February 2016/Accepted: 20 February 2016/Published online: 8 March 2016

(C) Islamic Azad University (IAU) 2016

\begin{abstract}
Nanosilica particles modified by Schiff base ligands 3-methoxy salicylaldimine propyl triethoxysilane $\left(\mathrm{MNS}_{1}\right)$, 5-bromo salicylaldimine propyl triethoxysilane $\left(\mathrm{MNS}_{2}\right)$ and 3-hydroxy salicylaldimine propyl triethoxysilane $\left(\mathrm{MNS}_{3}\right)$ were prepared, and their potential for separation of copper, lead, zinc, cadmium, cobalt and nickel ions from aqueous solutions was examined. The effect of parameters influencing adsorption efficiency including aqueous-phase $\mathrm{pH}$, amount of adsorbent, stirring time and initial concentration of the metal ions was assessed and discussed. Although $\mathrm{MNS}_{1}$ and $\mathrm{MNS}_{3}$ removed lead ions efficiently, all adsorbents showed strong selectivity toward copper ions. It was shown that, under some circumstances, $\mathrm{MNS}_{3}$ decreased the amount of other ions, particularly cobalt, in the aqueous phase. The adsorbents were also applied for removal of copper and lead ions from real samples. Possible quantitative desorption of the metal ions loaded onto the adsorbents suggests their multiple uses in adsorption-desorption process. Investigation of temperature dependency of the process led to determination of the $\Delta H^{\circ}, \Delta S^{\circ}$ and $\Delta G^{\circ}$ values. This investigation indicates that the adsorption of copper ions onto the all studied adsorbents and lead ions onto $\mathrm{MNS}_{1}$ and $\mathrm{MNS}_{3}$ is endothermic. The Langmuir, Freundlich, Temkin and Dubinin-Radushkevich isotherms were tested to describe
\end{abstract}

M. R. Yaftian

yaftian@znu.ac.ir

1 Phase Equilibria Research Laboratory, Department of Chemistry, Faculty of Science, University of Zanjan, P. O. Box 45371-38791, Zanjan, Iran

2 Inorganic Chemistry Research Laboratory, Department of Chemistry, Faculty of Science, University of Zanjan, P. O. Box 45371-38791, Zanjan, Iran the equilibrium data. Pseudo-first-order, pseudo-secondorder, Elovich and intra-particle diffusion equations were applied to study the kinetics of copper and lead adsorption onto the modified nanoparticles. This investigation indicates that the process for all adsorbents follows pseudosecond-order kinetics and suggests a chemisorption mechanism for the adsorption processes by the studied adsorbents.

Keywords Heavy metals · Removal · Silica nanoparticles · Modification $\cdot$ Schiff base ligands

\section{Introduction}

Pollution created by heavy metals is a serious environmental issue (Agrawal 2009). The removal of these ions from wastewater is the subject of extensive fundamental and industrial research (Fu and Wang 2011). The recovery of some heavy metals from secondary sources may also have economic benefits (Hoque and Philip 2011).

Nanosized materials play a substantial role in metal ion separation owing to their physical and chemical properties. The potential of these materials for removal of biomolecules (Janschm et al. 2012), organic (Yu et al. 2014) and inorganic (Önnby et al. 2014) species has been widely investigated.

Schiff base ligands bearing nitrogen/oxygen donor atoms have been shown to exhibit ionophoric properties, especially toward heavy metal ions (Shokrolahi et al. 2007). These properties have been investigated by their application as modifier of octadecyl disks for separationconcentration of trace amounts of metal ions (Fathi et al. 2010; Shamsipur et al. 2000), as phase transfer agents of metal ions in liquid-liquid extraction (Oshima et al. 2003), 
as extractant in cloud point extraction procedures (Fathi and Yaftian 2009; Shemirani et al. 2006), as mobile carrier agents for the transport of metal ions through liquid membranes (Fathi et al. 2008) and as sensory molecules for preparation of cation-selective electrodes (Pilehvari et al. 2007).

Following our previous reports focused on the ionophoric properties of Schiff base receptors (Fathi et al. 2008; Fathi and Yaftian 2009; Fathi et al. 2010; Pilehvari et al. 2007 ) and the application of modified silica nanoparticles for removal of metal ions from water samples (Shiri-Yekta et al. 2013), the present study investigated the application of modified nanosilica particles (MNS) by three Schiff base ligands (Fig. 1) named 3-methoxy salicylaldimine propyl triethoxysilane $\left(\mathrm{MNS}_{1}\right)$, 5-bromo salicylaldimine propyl triethoxysilane $\left(\mathrm{MNS}_{2}\right)$ and 3-hydroxy salicylaldimine propyl triethoxysilane $\left(\mathrm{MNS}_{3}\right)$ as adsorbents for removal of copper, lead, cobalt, nickel, zinc and cadmium ions from aqueous solutions. The parameters affecting the adsorption properties of the studied adsorbents were investigated and discussed. Experimental equilibrium data were evaluated using the Langmuir, Freundlich, Temkin and Dubinin-

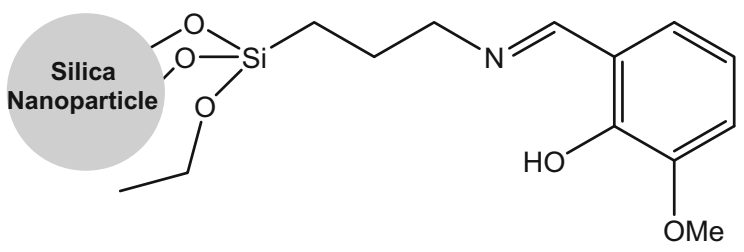

3-Methoxy salicylaldimine propyl triethoxysilane $\left(\mathrm{MNS}_{1}\right)$

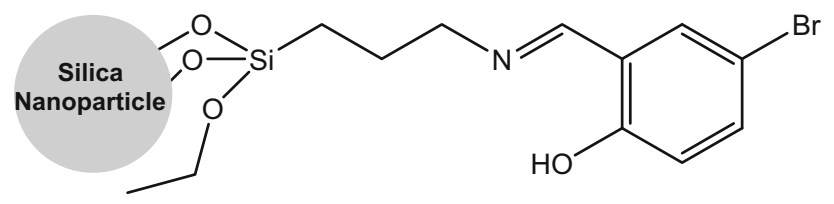

5-Bromo salicylaldimine propyl triethoxysilane $\left(\mathrm{MNS}_{2}\right)$

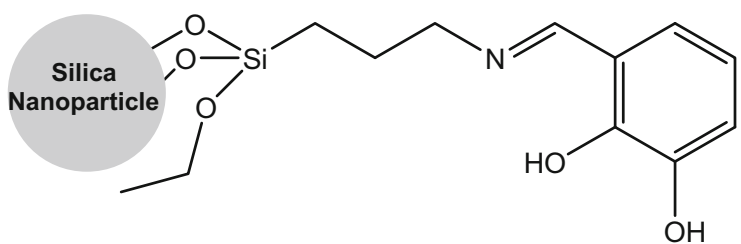

3-Hydroxy salicylaldimine propyl triethoxysilane $\left(\mathrm{MNS}_{3}\right)$

Fig. 1 Structure of the modified silica nanoparticles
Radushkevich isotherm models. Pseudo-first-order, pseudo-second-order, Elovich and intra-particle diffusion equations were tested to determine the kinetics of the adsorption process.

Beside the advantages of Schiff base ligands to bind efficiently heavy metal ions and the high surface area provided by nanosilica materials, the use of relatively lowcost materials in the preparation of the studied adsorbents allows this type of adsorbents to be considered as potential candidates for removal of heavy metal ions from water solutions. To the best of our knowledge, the preparation of the studied modified nanosilica particles and their application for removal of the target ions were not previously reported.

This study was wholly carried out at the Department of Chemistry, University of Zanjan (Iran), between November 2013 and October 2014.

\section{Materials and methods}

\section{Chemicals}

Methanol, toluene, amino propyl triethoxysilane, 2-hydroxy-3-methoxy benzaldehyde, 5-bromo-2-hydroxy benzaldehyde, 2,3-dihydroxy benzaldehyde, hydrochloric acid, nitric acid and sulfuric acid (Merck) were used as received. Unmodified nanoparticles (APS 20-30 nm) were purchased from Iranian Nanomaterial Pioneers. Stock solutions of the heavy metal ions $\left(1000 \mathrm{mg} \mathrm{L}^{-1}\right)$ were prepared using corresponding nitrate salts (Merck or Fluka). The stock solutions were standardized complexometrically (Dean 1995). Working solutions were prepared by suitable dilution of the stock solutions with distilled water.

\section{Apparatus}

${ }^{1} \mathrm{H}$ NMR and ${ }^{13} \mathrm{C}$ NMR measurements were taken using a FT-Bruker spectrometer (AVC $250 \mathrm{MHz}$ ), and the data were referenced relative to residual protonated solvents (7.26 ppm for $\mathrm{CDCl}_{3}$ ). FT-IR spectra were recorded on a Thermo-Nicolet-is10 FT-IR spectrometer. The pH adjustments were performed using a Metrohm digital $\mathrm{pH}$ meter (model 780) equipped with a combined glass electrode. An Ika magnetic stirrer (MR $3001 \mathrm{~K}$ ) was used for dispersing the adsorbent particles in the aqueous solutions. The temperature of the experiment vessels was controlled using a Julabo MP5 thermostat water circulator. Flame atomic absorption spectroscopy (FAAS; Varian 220AA) was used for metal ion determinations in water solutions. A furnace (Exiton, model Atash-1200) was used for activation of the silica nanoparticle surfaces before modification. The 
separation of adsorbents from aqueous solution was assisted by a high-speed centrifuge (Sigma, 3-30 K). Distilled water was passed through a filter (TKA-Gen Pure) before use for preparation of aqueous solutions. The SEM photograph was taken by a Philips XL30 scanning microscope.

\section{Preparation of adsorbents}

Modification of silica nanoparticles was carried out according to the reported procedure elsewhere (Ghorbanloo et al. 2011). Condensation of amino propyl triethoxysilane with 2-hydroxy-3-methoxy benzaldehyde, 5-bromo-2-hydroxy benzaldehyde and 2,3-dihydroxy benzaldehyde in methanol produced 3-methoxy salicylaldimine propyl triethoxysilane, 5-bromo salicylaldimine propyl triethoxysilane and 3-hydroxy salicylaldimine propyl triethoxysilane, respectively. The prepared Schiff base ligands were characterized by ${ }^{1} \mathrm{HNMR},{ }^{13} \mathrm{CNMR}$ and FT-IR spectra. By refluxing the synthesized Schiff base ligands with nanosized silica in toluene, the adsorbents $\mathrm{MNS}_{1}, \mathrm{MNS}_{2}$ and $\mathrm{MNS}_{3}$ were resulted. Elemental analysis indicated that the amount of imine grafted on $\mathrm{MNS}_{1}, \mathrm{MNS}_{2}$ and $\mathrm{MNS}_{3}$ was $0.34 \times 10^{-3}, 0.44 \times 10^{-3}$ and $0.49 \times 10^{-3}$ mol imine $\mathrm{g}^{-1}$, respectively. Figure 2 shows, as example, the SEM of the adsorbent $\mathrm{MNS}_{1}$. SEM allowed examining the morphology and surface structure of the adsorbents at the required magnification.

Comparison of the FT-IR spectra of the unloaded and loaded modified adsorbents by copper ions was used for

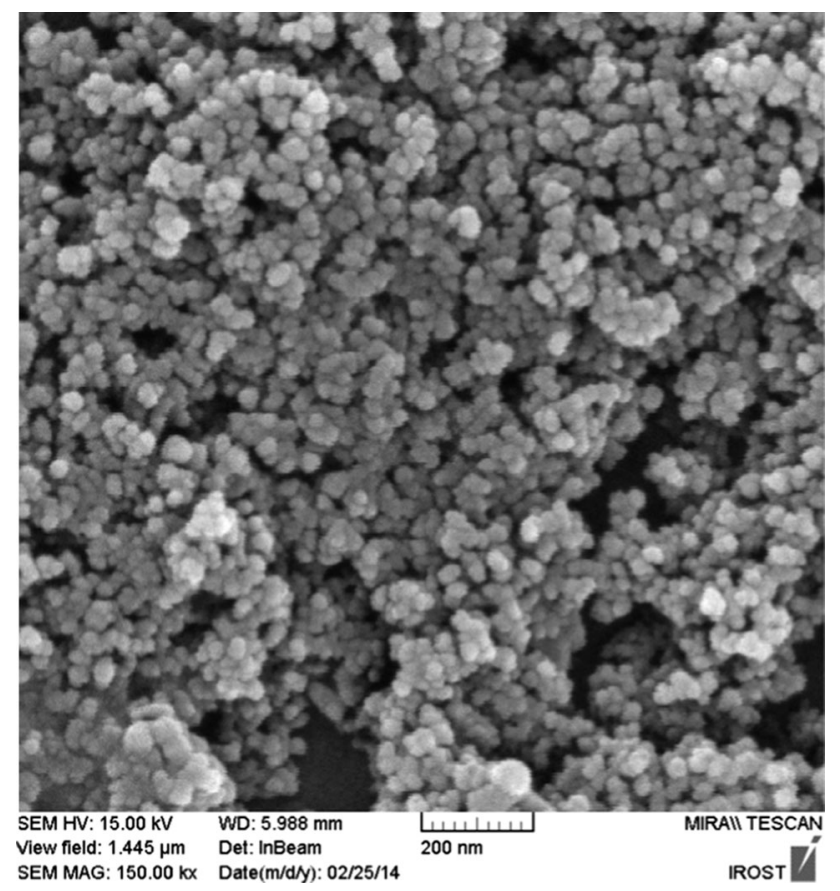

Fig. 2 SEM of the modified $\mathrm{MNS}_{1}$ characterization of the metal ion complexed by the ligating groups anchored on the adsorbents. A peak at 1653.5, 1648.3 and $1648.5 \mathrm{~cm}^{-1}$ is attributed to the $\mathrm{C}=\mathrm{N}$ bond for $\mathrm{MNS}_{1}, \mathrm{MNS}_{2}$ and $\mathrm{MNS}_{3}$, respectively. After adsorption of copper ions, these peaks shift to the lower values at 1634.6, 1632.3 and $1647.4 \mathrm{~cm}^{-1}$, respectively. This shift shows the participation of $\mathrm{C}=\mathrm{N}$ bonds on the complexation of copper ions. The presence of water molecules prohibits characterizing the possible participation of oxygen atoms on the complexation of the metal ions.

\section{Adsorption}

The adsorption experiments were carried out in stoppered plastic vessels using $0.1 \mathrm{~g}$ of adsorbent in $20 \mathrm{~mL}$ of sample containing $\mathrm{Cu}^{2+}, \mathrm{Pb}^{2+}, \mathrm{Co}^{2+}, \mathrm{Ni}^{2+}, \mathrm{Zn}^{2+}$ and $\mathrm{Cd}^{2+}$ ions $\left(20 \mathrm{~m} \mathrm{~L} \mathrm{~L}^{-1}\right)$. It was confirmed that adsorption equilibrium was reached after $50 \mathrm{~min}$ of magnetic stirring at $25^{\circ} \mathrm{C}$. After separation of the phases by centrifugation (20,000 rpm), the cation concentration remaining in the aqueous phase was measured by FAAS. The percentage of ion uptake and the percentage of ion desorption were calculated using Eqs. 1 and 2, respectively:

Uptake $\%=\frac{\left(C_{0}-C_{\mathrm{e}}\right)}{C_{0}} \times 100$

Desorption $\%=\frac{m_{\mathrm{d}}}{m_{\mathrm{a}}} \times 100$

where $C_{0}$ and $C_{\mathrm{e}}$ are the initial and equilibrium concentration of ions $\left(\mathrm{mg} \mathrm{L}^{-1}\right)$, respectively, and $m_{\mathrm{d}}$ and $m_{\mathrm{a}}(\mathrm{mg})$ are the desorbed and adsorbed mass of ions, respectively.

\section{Results and discussion}

\section{Effect of pH on adsorption}

Since the ionization of hydroxyl groups of Schiff base ligands grafted onto the nanosilica matrix depends on the aqueous-phase $\mathrm{pH}$, this parameter plays an important role on the adsorption efficiency. Figure 3 shows a significant increase in adsorption of copper ions by increasing the aqueous-phase $\mathrm{pH}$. Similar result was observed for the adsorption of lead ions onto $\mathrm{MNS}_{1}$ and $\mathrm{MNS}_{3}$. An increase in the aqueous-phase $\mathrm{pH}$ reduces the competition of $\mathrm{H}^{+}$ ions and metal cations for adsorption sites. These finding suggest an ion exchange mechanism for the adsorption of the studied ions onto the adsorbents.

A comparison of the results obtained for unmodified nanoparticles (NS) and modified nanoparticles $\left(\mathrm{MNS}_{1}\right.$, $\mathrm{MNS}_{2}$ and $\mathrm{MNS}_{3}$ ) reveals that modification remarkably increases uptake of $\mathrm{Cu}^{2+}$ and $\mathrm{Pb}^{2+}$ ions. Although $\mathrm{MNS}_{1}$ 
Fig. 3 Effect of $\mathrm{pH}$ on competitive adsorption of ions (filled diamond $\mathrm{Cu}^{2+}$, filled square $\mathrm{Pb}^{2+}$, filled rectangle $\mathrm{Zn}^{2+}$, times $\mathrm{Cd}^{2+}$, asterisk $\mathrm{Co}^{2+}$, filled circle $\mathrm{Ni}^{2+}$ ) onto $\mathrm{NS}$ and $\mathrm{MNS}_{1}, \mathrm{MNS}_{2}$ and $\mathrm{MNS}_{3}\left(20 \mathrm{mg} \mathrm{L}^{-1}\right.$ initial concentration of metal ions; adsorbent $0.05 \mathrm{~g} ; 60 \mathrm{~min}$ stirring time; $25{ }^{\circ} \mathrm{C}$ )
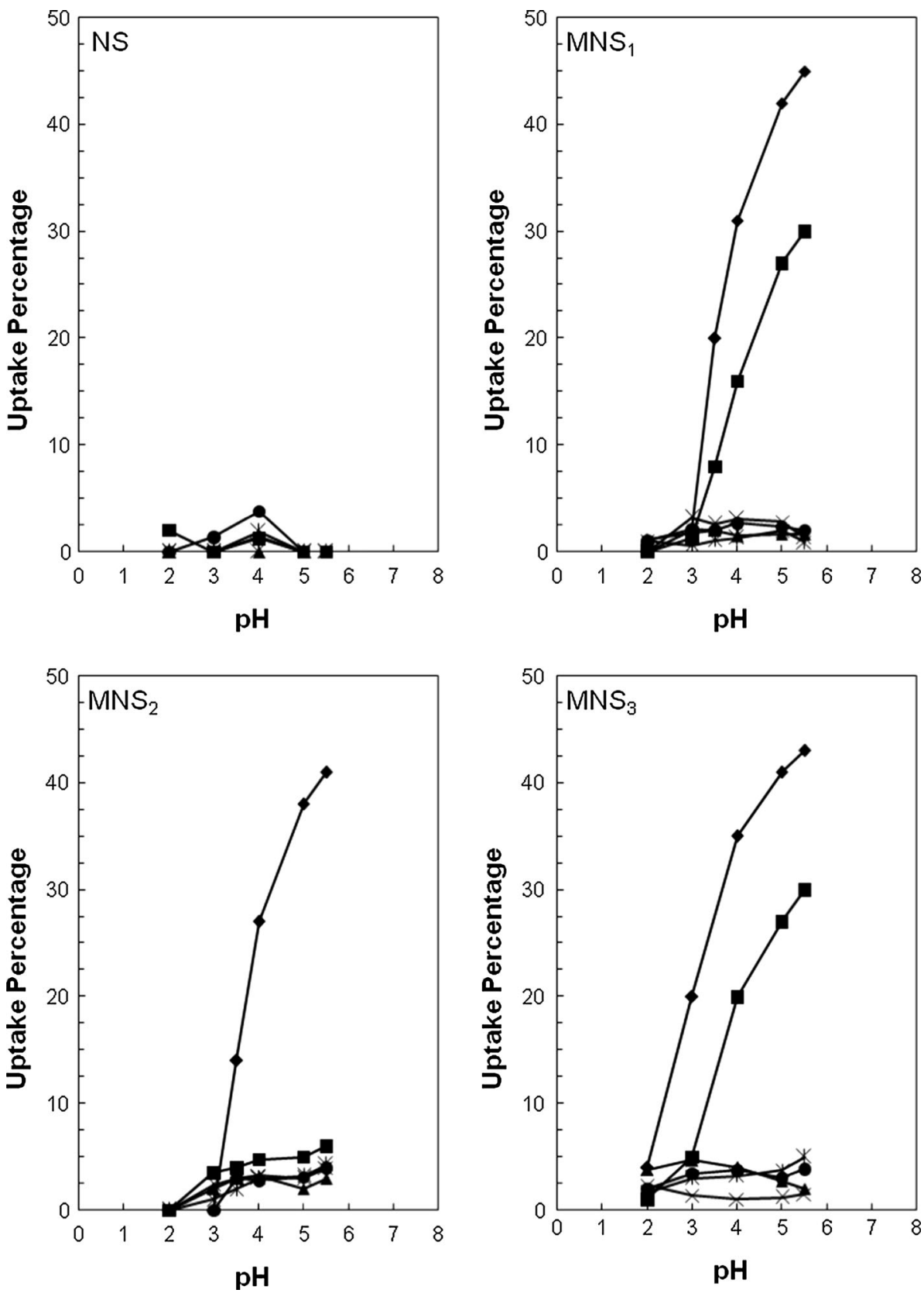

and $\mathrm{MNS}_{3}$ show good adsorption potential toward copper and lead ions, the best selectivity of copper ions was demonstrated by $\mathrm{MNS}_{2}$. The adsorption of other ions under selected experimental conditions was very weak and did not practically depend on the variation of the aqueousphase $\mathrm{pH}$. The higher extraction percentage of copper ions at lower $\mathrm{pH}$ values by $\mathrm{MNS}_{3}$ over $\mathrm{MNS}_{1}$ and $\mathrm{MNS}_{2}$ indicates the higher acidic nature of the hydroxyl group of the Schiff base grafted onto $\mathrm{MNS}_{3}$ with respect to the other examined adsorbents. This can be also attributed to the amount of the grafted complexing groups on the adsorbents (see "Materials and methods" section).

\section{Amount of adsorbent}

One of the parameters influencing the efficiency of the adsorption of metal ion from an aqueous solution is the employed amount of adsorbent. To determine the effect of this parameter on the efficiency of the studied adsorbents, a series of experiments were carried out using $0.025-0.2 \mathrm{~g}$ of $\mathrm{MNS}_{1}, \mathrm{MNS}_{2}$ and $\mathrm{MNS}_{3}$ for the removal of $\mathrm{Cu}^{2+}, \mathrm{Pb}^{2+}$, $\mathrm{Zn}^{2+}, \mathrm{Cd}^{2+}, \mathrm{Co}^{2+}$ and $\mathrm{Ni}^{2+}$ ions from aqueous phase, adjusted to $\mathrm{pH} 5$ (Fig. 4). By increasing the amount of adsorbent, the complexing groups available on the adsorbent surface increase and provide more adsorption sites for 


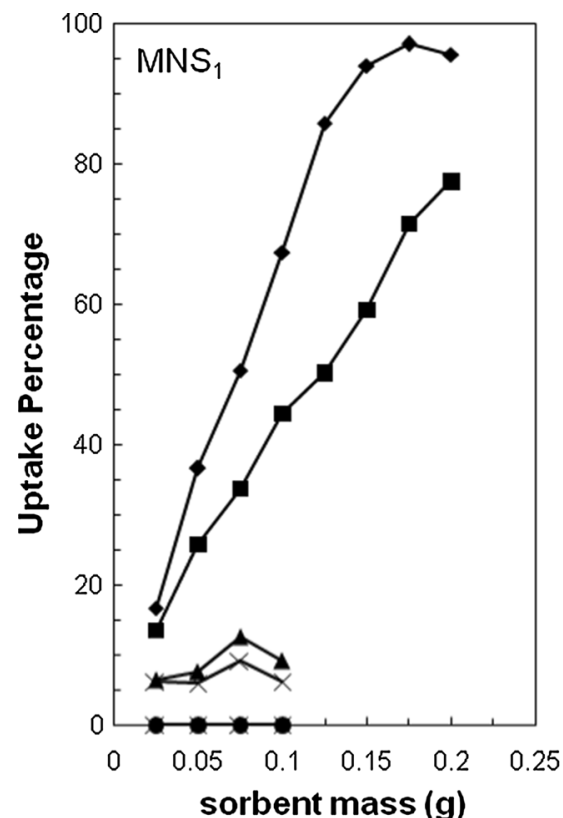

Fig. 4 Effect of amount of modified nanoparticles on adsorption efficiency of the studied metal ions (filled diamond $\mathrm{Cu}^{2+}$, filled square $\mathrm{Pb}^{2+}$, filled rectangle $\mathrm{Zn}^{2+}$, times $\mathrm{Cd}^{2+}$, asterisk $\mathrm{Co}^{2+}$, filled circle

the metal ions, and thus an increase in metal ion uptake takes place (Zhang et al. 2012). It was found that the use of more than $0.15 \mathrm{~g}$ of $\mathrm{MNS}_{1}, \mathrm{MNS}_{2}$ and $\mathrm{MNS}_{3}$ results in quantitative removal of copper ions from the aqueous phase. Although an amount of more than $0.2 \mathrm{~g}$ of $\mathrm{MNS}_{3}$ allows a quantitative elimination of lead ions, the lower efficiency of $\mathrm{MNS}_{1}$ inhibits the removal of these ions more than $80 \%$ by using the same mass of the adsorbent. The results obtained by $\mathrm{MNS}_{3}$ show also the potential of this adsorbent toward other examined ions. It is found that, by using $0.2 \mathrm{~g}$ of $\mathrm{MNS}_{3}, 40 \%$ of cobalt ions and $20 \%$ of zinc, cadmium and nickel ions can be removed from aqueous phase.

\section{Time dependency of process}

In order to optimize the time required for access to equilibrium condition, a series of adsorption experiments were performed. This investigation allows also verifying the kinetics of the process (see the section "kinetics of adsorption"). The adsorption of metal ions from aqueous solution (pH 5) using $0.1 \mathrm{~g}$ of adsorbent was studied by contacting the solid and liquid phases in the range 3-120 min (Fig. 5). Equilibrium of adsorption of copper ions was achieved after $10 \mathrm{~min}$ for $\mathrm{MNS}_{1}, 20 \mathrm{~min}$ for $\mathrm{MNS}_{2}$ and $50 \mathrm{~min}$ for $\mathrm{MNS}_{3}$. These results demonstrate that the kinetics of copper adsorption by $\mathrm{MNS}_{1}$ is more rapid than by the other studied adsorbents. It is also seen that the adsorption of lead ions onto $\mathrm{MNS}_{1}$ is more rapid than onto $\mathrm{MNS}_{3}$. An equilibrium condition for the removal

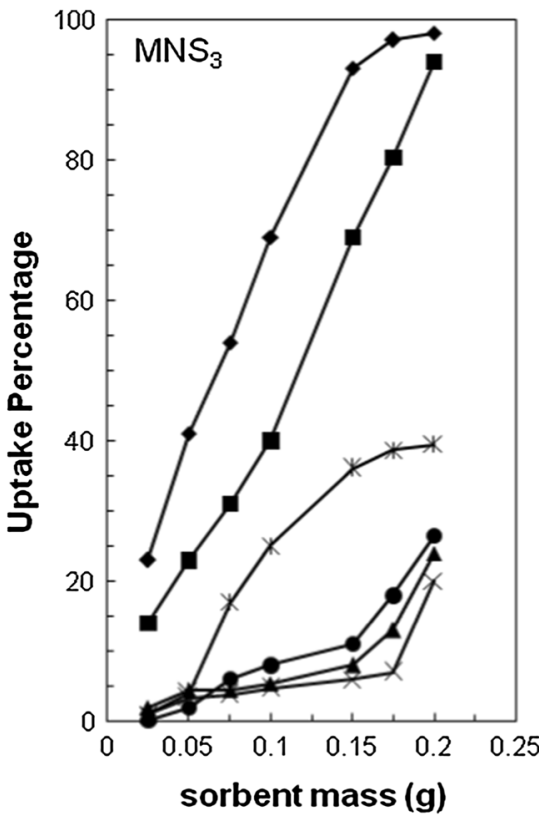

$\mathrm{Ni}^{2+}$ ). Experimental conditions: initial concentration of metal ions $20 \mathrm{mg} \mathrm{L}^{-1}$, aqueous-phase $\mathrm{pH} 5$, stirring time $60 \mathrm{~min}$, temperature $25^{\circ} \mathrm{C}$

of cobalt ions by $\mathrm{MNS}_{3}$ can be achieved after $60 \mathrm{~min}$ of stirring the phases.

\section{Initial concentration of metal ions}

It is found that an increase in initial metal ion concentration in the aqueous phase afforded an enhancement in the metal ion uptake (Fig. 6). The process was monitored by evaluating the maximum amount of metal ions adsorbed $\left(q_{\mathrm{m}}\right)$ by a given amount of adsorbent at $\mathrm{pH}$ 5. The $q_{\mathrm{m}}$ value for copper adsorption was $3.73 \mathrm{mg}$ by $\mathrm{MNS}_{1}, 4.12 \mathrm{mg}$ by $\mathrm{MNS}_{2}$ and $5.92 \mathrm{mg}$ by $\mathrm{MNS}_{3}$, per g of adsorbent. This value was 1.69 and $5.82 \mathrm{mg}$ lead per g of adsorbent for $\mathrm{MNS}_{1}$ and $\mathrm{MNS}_{3}$, respectively. These values are in agreement with the order of the amount of imines grafted onto modified nanosilica particles, which was determined by elemental analysis, as $0.34 \times 10^{-3}, 0.44 \times 10^{-3}$ and $0.49 \times 10^{-3} \mathrm{~mol}$ imine $\mathrm{g}^{-1}$ for $\mathrm{MNS}_{1}, \mathrm{MNS}_{2}$ and $\mathrm{MNS}_{3}$, respectively.

\section{Desorption}

A series of adsorption experiments were performed to examine the possibility of multiple uses of the adsorbents and evaluate their stability. In these experiments, $20 \mathrm{~mL}$ of aqueous solution containing $20 \mathrm{mg} \mathrm{L}^{-1}$ of copper and lead ions adjusted to $\mathrm{pH} 5$ was mixed with $0.2 \mathrm{~g}$ of the adsorbent and stirred magnetically for $60 \mathrm{~min}$. After separation of the phases, the metal ions remained in the aqueous phase was analyzed. The results showed $100 \%$ of $\mathrm{Cu}^{2+}$ ions by 

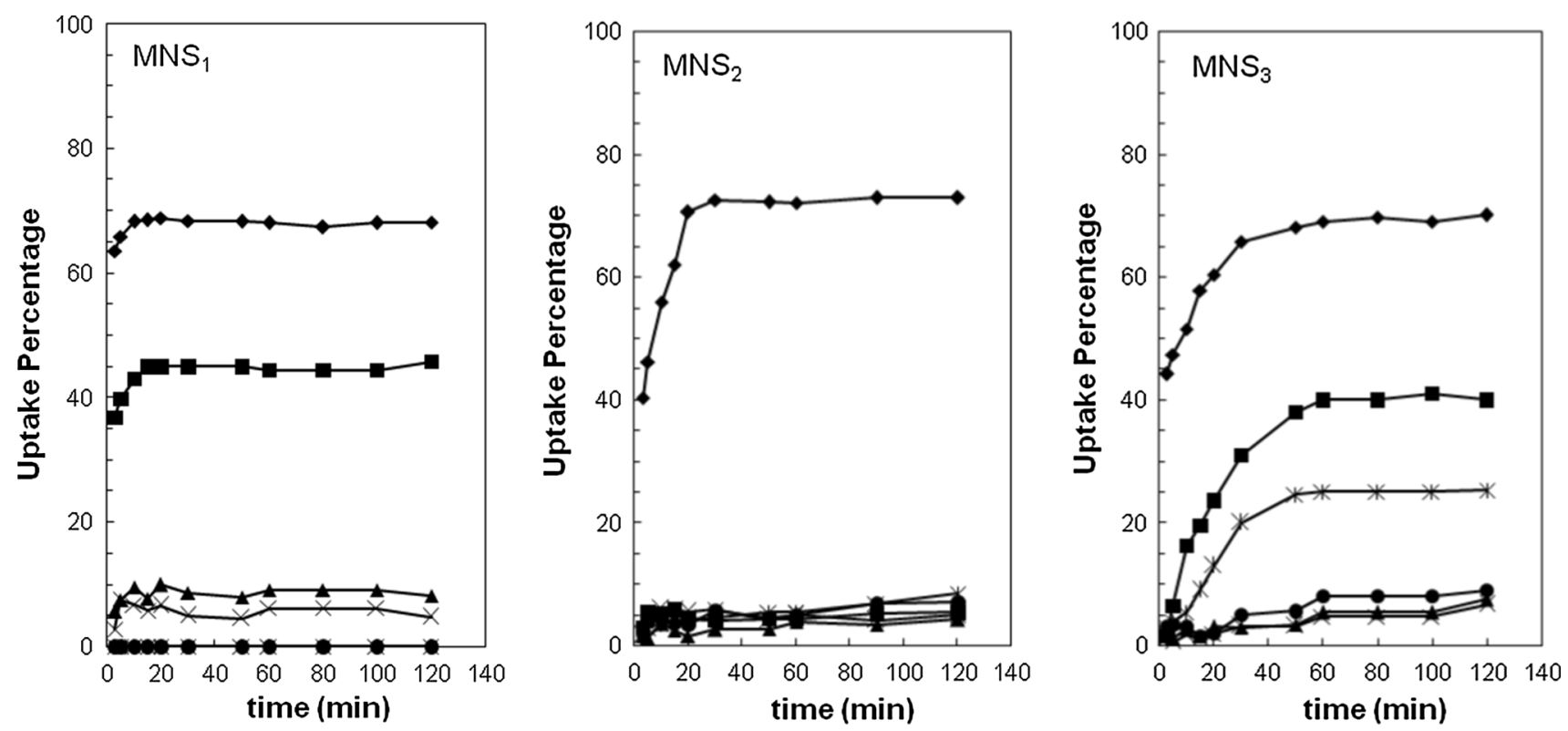

Fig. 5 Adsorption percentage of the studied metal ions (filled diamond $\mathrm{Cu}^{2+}$, filled square $\mathrm{Pb}^{2+}$, filled rectangle $\mathrm{Zn}^{2+}$, times $\mathrm{Cd}^{2+}$, asterisk $\mathrm{Co}^{2+}$, filled circle $\mathrm{Ni}^{2+}$ ) as a function of stirring time.

Experimental conditions: initial concentration of metal ions $20 \mathrm{mg} \mathrm{L}^{-1}$, adsorbent $0.1 \mathrm{~g}$, aqueous-phase $\mathrm{pH} 5$, temperature $25^{\circ} \mathrm{C}$
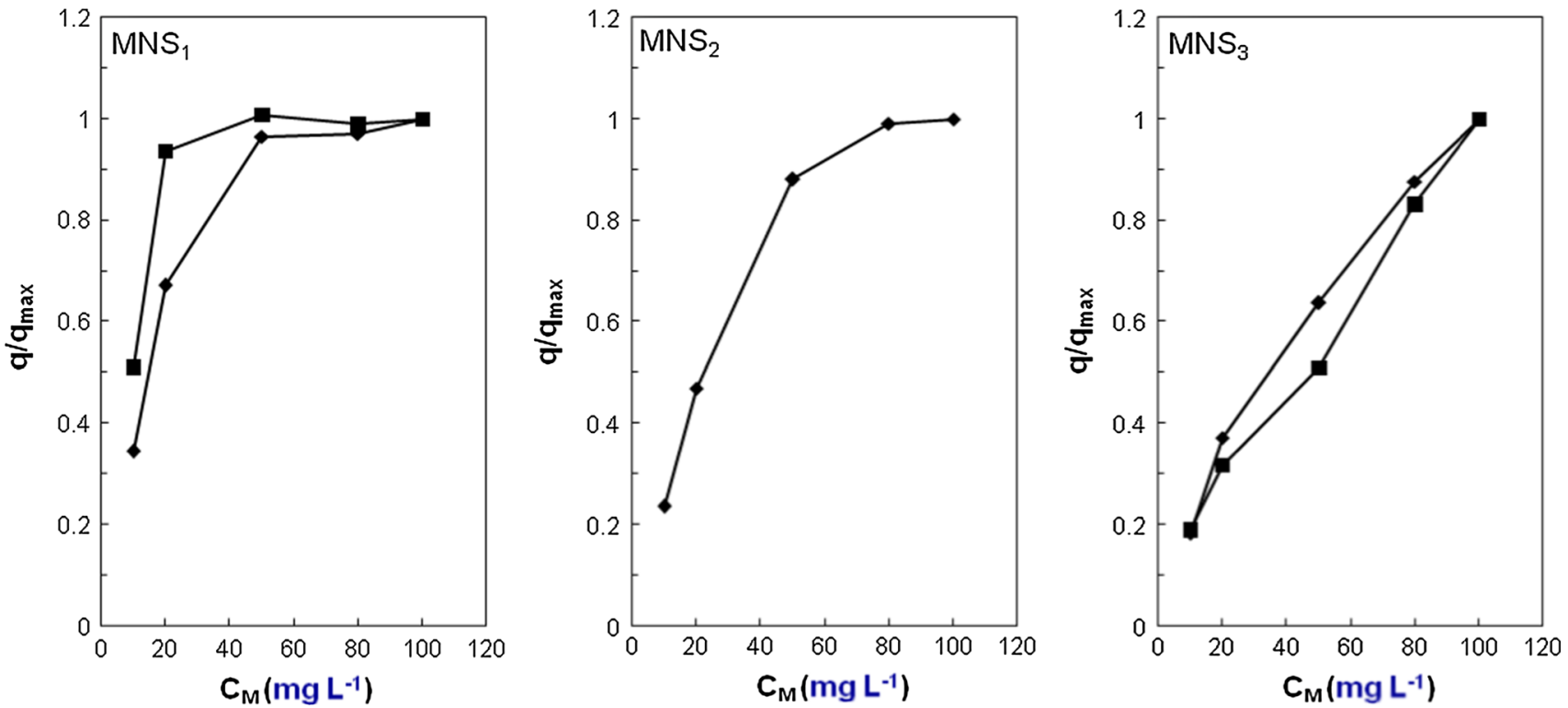

Fig. 6 Uptake of $\mathrm{Cu}^{2+}$ (filled diamond) and $\mathrm{Pb}^{2+}$ (filled square) ions by the studied adsorbents as a function of their initial concentrations in aqueous phase. Experimental conditions: adsorbent $0.15 \mathrm{~g}$, aqueous-phase $\mathrm{pH} 5$, stirring time $60 \mathrm{~min}$, temperature $25^{\circ} \mathrm{C}$

all the studied adsorbents and $80 \%$ of lead ions by $\mathrm{MNS}_{1}$ and $100 \%$ of lead ions by $\mathrm{MNS}_{2}$ were removed from the aqueous solutions. The adsorbents were washed twice using $5 \mathrm{~mL}$ of distilled water and then dried in an oven at $110{ }^{\circ} \mathrm{C}$. The loaded adsorbents were stripped with $5 \mathrm{~mL}$ of nitric acid, hydrochloric acid and sulfuric acid $\left(0.1 \mathrm{~mol} \mathrm{~L}^{-1}\right)$ for $60 \mathrm{~min}$ (Table 1). It is seen that hydrochloric acid solution $\left(5 \mathrm{~mL}, 0.1 \mathrm{~mol} \mathrm{~L}^{-1}\right)$ can quantitatively strip copper ions from $\mathrm{MNS}_{1}$ and $\mathrm{MNS}_{3}$.
Quantitative stripping of lead ions from $\mathrm{MNS}_{1}$ was achieved by hydrochloric or nitric acid solutions $\left(0.1 \mathrm{~mol} \mathrm{~L}^{-1}\right)$. For a quantitative stripping of copper ions from loaded $\mathrm{MNS}_{1}$ and lead ions from loaded $\mathrm{MNS}_{2}$, the stripped adsorbent from the first step was mixed with a second $5 \mathrm{~mL}$ solution of $0.1 \mathrm{~mol} \mathrm{~L}^{-1}$ hydrochloric acid. Under such conditions, all adsorbed metal ions transferred into the aqueous phase. The separated nanoparticles were used repeatedly for the experiments described above. There 
Table 1 Comparison of various acid solutions as strippant of loaded adsorbents ${ }^{\mathrm{a}}$

\begin{tabular}{|c|c|c|c|c|c|c|}
\hline \multirow[t]{2}{*}{ Strippant $\left(0.1 \mathrm{~mol} \mathrm{~L}^{-1}\right)$} & \multicolumn{2}{|l|}{$\mathrm{MNS}_{1}$} & \multicolumn{2}{|c|}{$\mathrm{MNS}_{2}$} & \multicolumn{2}{|c|}{$\mathrm{MNS}_{3}$} \\
\hline & $\overline{\mathrm{Cu}^{2+}}$ & $\mathrm{Pb}^{2+}$ & $\overline{\mathrm{Cu}^{2+}}$ & $\mathrm{Pb}^{2+}$ & $\overline{\mathrm{Cu}^{2+}}$ & $\mathrm{Pb}^{2+}$ \\
\hline $\mathrm{HCl}^{\mathrm{b}}$ & 100.0 & 100.0 & 81.5 & - & 98.7 & 78.0 \\
\hline $\mathrm{HCl}^{\mathrm{c}}$ & - & - & 20.0 & - & - & 24.4 \\
\hline $\mathrm{HNO}_{3}$ & 87.8 & 100.0 & 84.7 & - & 87.0 & 61.5 \\
\hline $\mathrm{H}_{2} \mathrm{SO}_{4}$ & 73.0 & 66.0 & 79.3 & - & 91.0 & 12.5 \\
\hline
\end{tabular}

a The values are in comparison with $100 \%$ of the copper and lead ions loaded onto the adsorbents

b First stripping by $5 \mathrm{ml}$ of hydrochloric acid

c Second stripping by $5 \mathrm{ml}$ of hydrochloric acid

\begin{tabular}{|c|c|c|c|c|c|c|}
\hline \multirow[t]{2}{*}{ Adsorbent } & \multicolumn{2}{|l|}{ Well water } & \multicolumn{2}{|l|}{ Tap water } & \multicolumn{2}{|l|}{ Molten snow } \\
\hline & $\mathrm{Cu}^{2+}$ & $\mathrm{Pb}^{2+}$ & $\mathrm{Cu}^{2+}$ & $\mathrm{Pb}^{2+}$ & $\mathrm{Cu}^{2+}$ & $\mathrm{Pb}^{2+}$ \\
\hline $\mathrm{MNS}_{1}$ & $99.4( \pm 1.1)$ & $99.2( \pm 1.4)$ & $100.0( \pm 0.3)$ & $93.5( \pm 0.6)$ & $100.0( \pm 0.5)$ & $96.5( \pm 0.2)$ \\
\hline $\mathrm{MNS}_{2}$ & $98.8( \pm 0.3)$ & - & $99.4( \pm 0.2)$ & - & $99.6( \pm 0.1)$ & - \\
\hline $\mathrm{MNS}_{3}$ & $99.8( \pm 0.2)$ & $98.4( \pm 0.1)$ & $100.0( \pm 0.5)$ & $98.9( \pm 1.0)$ & $100.0( \pm 0.6)$ & $99.3( \pm 0.8)$ \\
\hline
\end{tabular}

Experimental conditions: aqueous phase, $20 \mathrm{~mL}$ of the samples injected by $20 \mathrm{mg} \mathrm{L}^{-1}$ of copper and lead ions; $\mathrm{pH} 5$; adsorbent dose $0.2 \mathrm{~g}$; stirring time $60 \mathrm{~min}$; temperature $25^{\circ} \mathrm{C}$
Table 2 Results of the experiments evaluating the applicability of the adsorbents for removal of copper and lead ions from real samples from their mixture by the modified nanoparticles was examined in the range 293-343 K. The distribution coefficient $\left(K_{\mathrm{d}}\right)$ was calculated as:

$K_{\mathrm{d}}=\frac{q_{\mathrm{e}}}{C_{\mathrm{e}}}$

\section{Applications}

A series of experiments was designed to assess the applicability of the proposed method for removal of copper and lead ions from water samples. Three water samples (tap and well water samples from the University of Zanjan campus, and a sample of molten snow) were first digested by nitric acid solution. The resulting solutions were spiked with copper and lead ions $\left(20 \mathrm{mg} \mathrm{L}^{-1}\right)$. A volume of $20 \mathrm{~mL}$ of samples adjusted to $\mathrm{pH} 5$ was stirred with $0.2 \mathrm{~g}$ of adsorbent at room temperature. After $60 \mathrm{~min}$ of magnetic stirring, the solid particles were separated from the aqueous phase by centrifugation. The concentration of metal ions remaining in the aqueous phase was determined by FAAS. These experiments were repeated three times, and the results are shown in Table 2. It was found that copper ions were completely removed under selected conditions by all the examined adsorbents. A quantitative removal of $\mathrm{Pb}^{2+}$ ions was attained by using $\mathrm{MNS}_{1}$ and $\mathrm{MNS}_{2}$ adsorbents.

\section{Temperature dependency and thermodynamics of process}

To verify the influence of temperature on the process, the removal of $\mathrm{Cu}^{2+}, \mathrm{Pb}^{2+}, \mathrm{Co}^{2+}, \mathrm{Ni}^{2+}, \mathrm{Zn}^{2+}$ and $\mathrm{Cd}^{2+}$ ions where $q_{\mathrm{e}}$ is the quantity of analyte adsorbed onto the adsorbent ( $\mathrm{mg} \mathrm{g}^{-1}$ ) and $C_{\mathrm{e}}$ is the concentration of metal remaining in solution at equilibrium $\left(\mathrm{mg} \mathrm{L}^{-1}\right)$.

The free energy changes $\left(\Delta G^{\circ}\right)$ for the adsorption equilibrium is calculated from the distribution coefficients:

$\Delta G^{\circ}=-\mathrm{RT} \ln K_{\mathrm{d}}$

and is related to the enthalpy $\left(\Delta H^{\circ}\right)$ and entropy $\left(\Delta S^{\circ}\right)$ changes through the Gibbs-Helmholtz equation:

$\Delta G^{\circ}=\Delta H^{\circ}-T \Delta S^{\circ}$

It is possible to determine $\Delta G^{\circ}, \Delta H^{\circ}$ and $\Delta S^{\circ}$ using the plots of $\ln K_{\mathrm{d}}$ versus $T^{-1}$ and Eq. 6:

$\ln K_{\mathrm{d}}=-\frac{\Delta H^{\circ}}{R T}+\frac{\Delta S^{\circ}}{R}$

Figure 7 reveals that adsorption efficiency increases as temperature increases. Table 3 lists the corresponding thermodynamic values. These values reveal that all adsorption processes were endothermic and controlled by changes in entropy. A positive change in enthalpy results from the dehydration of metal ions during adsorption ( $\mathrm{Tu}$ et al. 2012). This dehydration requires an amount of energy that surpasses that from the heat released by the adsorption reaction (Liu et al. 2013). 

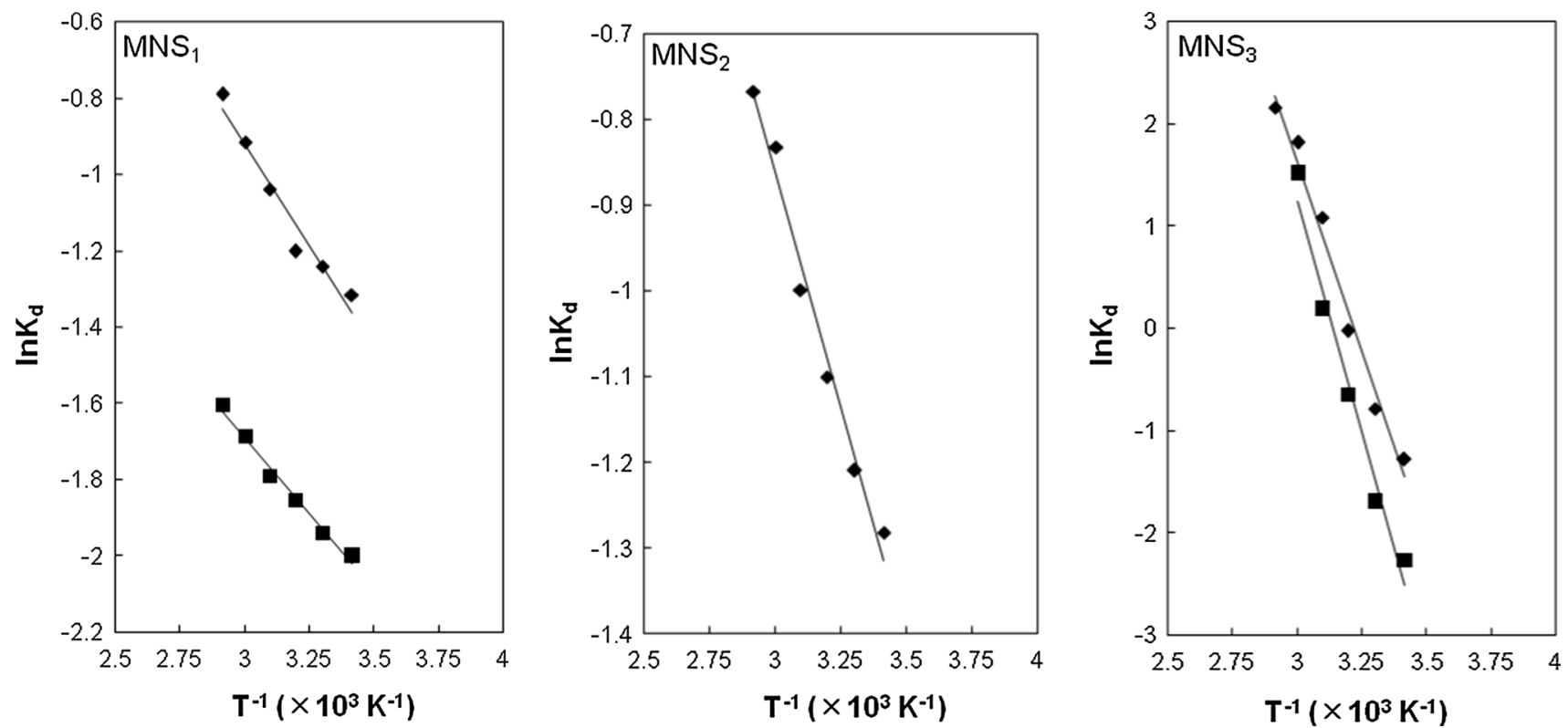

Fig. 7 Variation of $\ln K_{d}$ versus $T^{-1}$ for adsorption of $\mathrm{Cu}^{2+}$ (filled diamond) and $\mathrm{Pb}^{2+}$ (filled square) ions onto $\mathrm{MNS}_{1}, \mathrm{MNS}_{2}$ and $\mathrm{MNS}_{3}$. Experimental conditions: adsorbent $0.075 \mathrm{~g}$, aqueous-phase $\mathrm{pH} 5$; stirring time $60 \mathrm{~min}$

Table 3 Thermodynamic parameters (in $\mathrm{kJ} \mathrm{mol}^{-1}$ ) for the adsorption of copper and lead ions onto $\mathrm{MNS}_{1}, \mathrm{MNS}_{2}$ and $\mathrm{MNS}_{3}$ at $298 \mathrm{~K}$

\begin{tabular}{llccl}
\hline Adsorbent & Metal ion & $\Delta H^{\circ}$ & $T \Delta S^{\circ}$ & $\Delta G^{\circ}$ \\
\hline $\mathrm{MNS}_{1}$ & $\mathrm{Cu}^{2+}$ & 8.93 & 5.71 & 3.22 \\
& $\mathrm{~Pb}^{2+}$ & 6.67 & 1.77 & 4.89 \\
$\mathrm{MNS}_{2}$ & $\mathrm{Cu}^{2+}$ & 9.04 & 5.95 & 3.10 \\
& $\mathrm{~Pb}^{2+}$ & - & - & - \\
$\mathrm{MNS}_{3}$ & $\mathrm{Cu}^{2+}$ & 62.35 & 59.81 & 2.54 \\
& $\mathrm{~Pb}^{2+}$ & 76.30 & 71.35 & 4.95 \\
\hline
\end{tabular}

$\mathrm{SD}< \pm 0.60$

\section{Adsorption isotherms}

To determine the most suitable isotherm for describing the experimental data, the Langmuir, Freundlich, Temkin and Dubinin-Radushkevich (D-R) isotherms were considered and applied to the experimental data.

The Langmuir isotherm considers monolayer coverage of the adsorption surface. The equation describing this isotherm is shown in Eq. 7:

$\frac{C_{\mathrm{e}}}{q_{\mathrm{e}}}=\frac{1}{q_{\mathrm{m}} K_{\mathrm{L}}}+\frac{C_{\mathrm{e}}}{q_{\mathrm{m}}}$

in which $C_{\mathrm{e}}$ is the equilibrium concentration of metal ions in solution (mg $\mathrm{L}^{-1}$ ), $q_{\mathrm{e}}$ is the amount of metal ions adsorbed per unit mass of adsorbent under equilibrium conditions $\left(\mathrm{mg} \mathrm{g}^{-1}\right), q_{\mathrm{m}}$ is the maximum adsorption capacity $\left(\mathrm{mg} \mathrm{g}^{-1}\right)$, and $K_{\mathrm{L}}$ is the Langmuir constant related to the adsorption energy $\left(\mathrm{L} \mathrm{mg}^{-1}\right)$. A plot of $C_{\mathrm{e}} /$ $q_{\mathrm{e}}$ versus $C_{\mathrm{e}}$ allows determination of $q_{\mathrm{m}}$ and $K_{\mathrm{L}}$. The separation factor or equilibrium parameter $\left(R_{\mathrm{L}}\right)$ is a useful dimensionless parameter which indicates the probability of the occurrence of adsorption. This parameter is expressed in Eq. 8:

$R_{\mathrm{L}}=\frac{1}{1+K_{\mathrm{L}} C_{0}}$

A process is unfavorable if $R_{\mathrm{L}}>1.0$ or $R_{\mathrm{L}}<0$; is linear favorable if $R_{\mathrm{L}}=1$; and is favorable if the value of $R_{\mathrm{L}}$ falls between 0 and 1. An irreversible process occurs when $R_{\mathrm{L}}=0$ (Zhang et al. 2012).

The Freundlich isotherm suggests that the uptake of metal ions occurs on a heterogeneous surface by multilayer adsorption (Jiang et al. 2009). The mathematical expression for the Freundlich isotherm is shown by Eq. 9:

$\log q_{\mathrm{e}}=\log K_{\mathrm{F}}+\frac{1}{n} \log C_{\mathrm{e}}$

where $K_{\mathrm{F}}$ and $n$ are Freundlich constants for adsorption capacity and adsorption intensity, respectively. In this model, $n$ is greater than unity and smaller value for $1 / n$ indicates stronger interaction between adsorbent and solute.

The Temkin isotherm assumes that the heat of adsorption decreases linearly versus coverage rather than logarithmically, as for the Freundlich equation (Ghasemi et al. 2012). The equation describing this isotherm is:

$q_{\mathrm{e}}=\frac{R T}{b} \ln K_{T}+\frac{R T}{b} \ln C_{\mathrm{e}}$ 
where $R$ is the gas constant $\left(0.0083 \mathrm{~kJ} \mathrm{~mol}^{-1} \mathrm{~K}^{-1}\right), T$ is the absolute temperature $(\mathrm{K}), b$ is the Temkin constant related to heat of adsorption $\left(\mathrm{kJ} \mathrm{mol}^{-1}\right)$, and $K_{\mathrm{T}}$ is the Temkin isotherm constant $\left(\mathrm{L} \mathrm{g} \mathrm{g}^{-1}\right)$. Parameters $K_{\mathrm{T}}$ and $b$ can be estimated by drawing the variation of $q_{\mathrm{e}}$ as a function of $\ln C_{\mathrm{e}}$.

The D-R isotherm does not assume homogeneous or constant adsorption potential for the surface (Lin and Juang 2002). The equation describing $\mathrm{D}-\mathrm{R}$ is given by Eq. 11:

$\ln q_{\mathrm{e}}=\ln q_{\mathrm{m}}-K_{\mathrm{D}-\mathrm{R}} \varepsilon^{2}$

Here $K_{\mathrm{D}-\mathrm{R}}\left(\mathrm{mol}^{2} \mathrm{~J}^{-2}\right)$ is a constant related to adsorption energy and $\varepsilon$ is the Polanyi potential as defined by Eq. 12:

$\varepsilon=R T \ln \left(1+\frac{1}{C_{e}}\right)$

A plot of the variation of $\ln q_{\mathrm{e}}$ as a function of $\varepsilon^{2}$ allows evaluating the parameters $K_{\mathrm{D}-\mathrm{R}}$ and $q_{\mathrm{m}} . E$ is the mean energy $\left(\mathrm{kJ} \mathrm{mol}^{-1}\right)$ required to bring a mole of adsorbate from infinity to the surface of the adsorbent (Ozcan et al. 2006). It can be calculated by Eq. 13:

$E=\frac{1}{\sqrt{2 K_{\mathrm{D}-\mathrm{R}}}}$

This parameter is used to estimate the type of adsorption. The value of $E<8 \mathrm{~kJ} \mathrm{~mol}^{-1}$ shows a physical nature for the adsorption. Adsorption is explained by the ion exchange mechanism if $E$ is greater than 8 and smaller than $16 \mathrm{~kJ} \mathrm{~mol}^{-1}$.

The parameters for the Langmuir, Freundlich, Temkin and D-R isotherms are shown in Table 4. A comparison of $R^{2}$ values that correspond to the tested isotherms confirms that the adsorption of both copper and lead ions onto $\mathrm{MNS}_{1}$ obeys the Langmuir model (Fig. 8a). The variation of $\ln q_{\mathrm{e}}$ versus $\varepsilon^{2}$ based on the D-R isotherm presents two linear ranges. The $R^{2}$ of the second linear range indicates that this model is valid for the adsorption of copper onto $\mathrm{MNS}_{1}$ in this region (Fig. 8b). Except for copper ion adsorption onto $\mathrm{MNS}_{2}$ in the first linear range explained by D-R (Fig. 9d), the adsorption of ions onto $\mathrm{MNS}_{2}$ could be described by all isotherms (Fig. 9).

Although the Langmuir isotherm was more suitable for lead ion adsorption onto $\mathrm{MNS}_{3}$ (Fig. 10a), the removal of copper ions by this adsorbent obeyed both the Langmuir and Temkin isotherms (Fig. 10). The results for the Langmuir and D-R models (Table 4) show acceptable agreement between the calculated and experimental values of $q_{\mathrm{m}}\left(q_{\mathrm{m} \text {,exp }}\right.$ and $\left.q_{\mathrm{m} \text {,cal }}\right)$. The $R_{\mathrm{L}}$ values calculated by the Langmuir isotherm indicate that the processes were favorable. The $n$ values derived from Freundlich isotherm reveal favorable processes for all types of adsorption. Table 4 shows that the values for $1 / n$ derived from the
Freundlich model were $0.038-0.472$. This confirms that the metal ions were favorably adsorbed by the modified adsorbents. Based on this parameter, the interaction between the adsorbed ion and the adsorbents varies as $\mathrm{Pb}^{2+} / \mathrm{MNS}_{1}<\mathrm{Cu}^{2+} / \mathrm{MNS}_{1}<\mathrm{Cu}^{2+} / \mathrm{MNS}_{2}<\mathrm{Pb}^{2+} /$ $\mathrm{MNS}_{3}<\mathrm{Cu}^{2+} / \mathrm{MNS}_{3}$.

Table 5 shows the adsorption capacity and the time required for achieving equilibrium condition for the removal of copper and lead ions by the studied adsorbents in the present work, and those found by using the adsorbents $\quad p$-dimethylaminobenzaldehyde-modified nanometer $\mathrm{SiO}_{2}, \mathrm{SiO}_{2}$-DMABD, (Cui et al. 2006), sodium dodecyl sulfate-coated poly(vinyl)chloride modified with bis(2-hydroxyacetophenone)-1,4-butanediimine, SDSPVC-BHABDI, (Marahel et al. 2009) and Schiff basemodified nanocomposite, $\mathrm{Fe}_{3} \mathrm{O}_{4} / \mathrm{SiO}_{2}-\mathrm{Pr}-\mathrm{N}=$ salicylaldehyde, (Moradinasab and Behzad 2014). The comparison of the data presented in Table 5 shows, although the capacity of $\mathrm{SiO}_{2}$-DMABD and modified nanocomposite $\mathrm{Fe}_{3} \mathrm{O}_{4} / \mathrm{SiO}_{2}$ toward copper ions is remarkably higher than the studied adsorbents, these adsorbents are more efficacious materials with respect to the modified SDS-PVC adsorbent. $\mathrm{MNS}_{3}$ shows comparable capacity toward lead ions in comparison with $\mathrm{SiO}_{2}$-DMABD. However, it presents higher adsorption potential toward lead ions than SDS-PVC-modified adsorbent. The time required for achieving equilibrium condition of adsorption of lead and copper ions (Table 5) reveals that the adsorption process onto $\mathrm{MNS}_{1}$ is more rapid than the other compared adsorbents. It is seen that the equilibrium time for the copper adsorption by $\mathrm{MNS}_{2}$ is reached after $20 \mathrm{~min}$, which is the same as that for $\mathrm{SiO}_{2}$-DMABD. More rapid kinetics of the adsorption of copper ions was observed by $\mathrm{MNS}_{1}, \mathrm{MNS}_{2}$ and $\mathrm{MNS}_{3}$, with respect to the modified nanocomposite $\mathrm{Fe}_{3} \mathrm{O}_{4} / \mathrm{SiO}_{2}$.

\section{Prediction of multi-component adsorption equilibrium}

Multi-component adsorption systems involve competition among the heavy metals to occupy limited available adsorbent surface sites and the interactions between different adsorbates. Multi-component models are used to predict multi-component adsorptions equilibrium from single-component systems. Numerous models have been proposed to give a mathematical description of this proposition (Ho and McKay 2000; Wurster et al. 2000; Dabrowski et al. 2005). We selected Langmuir multicomponent model, because the results of adsorption isotherms show this model describes suitably the singlecomponent experimental results.

In order to correlate the results of multiple-component system to those of single component, Butler and Ockrent 
Table 4 Parameters evaluated by using various isotherms for the adsorption of copper and lead ions onto the studied adsorbents

\begin{tabular}{|c|c|c|c|c|c|c|}
\hline \multirow[t]{2}{*}{ Isotherm type } & \multirow[t]{2}{*}{ Parameter } & \multicolumn{2}{|l|}{$\mathrm{MNS}_{1}$} & \multirow{2}{*}{$\begin{array}{l}\mathrm{MNS}_{2} \\
\mathrm{Cu}^{2+}\end{array}$} & \multicolumn{2}{|l|}{$\mathrm{MNS}_{3}$} \\
\hline & & $\mathrm{Cu}^{2+}$ & $\mathrm{Pb}^{2+}$ & & $\mathrm{Cu}^{2+}$ & $\mathrm{Pb}^{2+}$ \\
\hline \multirow[t]{5}{*}{ Langmuir } & $q_{\mathrm{m}, \exp }\left(\mathrm{mg} \mathrm{g}^{-1}\right)$ & 3.73 & 1.69 & 4.2 & 5.92 & 5.82 \\
\hline & $K_{\mathrm{L}}\left(\mathrm{L} \mathrm{mg}^{-1}\right)$ & 0.78 & 3.31 & 0.57 & 0.14 & 0.27 \\
\hline & $q_{\mathrm{m}, \mathrm{cal}}\left(\mathrm{mg} \mathrm{g}^{-1}\right)$ & 3.61 & 1.77 & 3.78 & 5.92 & 2.51 \\
\hline & $R_{\mathrm{L}}$ & 0.06 & 0.01 & 0.08 & 0.26 & 0.16 \\
\hline & $R^{2}$ & 0.994 & 0.998 & 0.997 & 0.991 & 0.994 \\
\hline \multirow[t]{4}{*}{ Freundlich isotherm } & $K_{\mathrm{F}}\left(\left(\mathrm{mg} \mathrm{g}^{-1}\right) /\left(\mathrm{mg} \mathrm{L}^{-1}\right)^{1 / n}\right)$ & 2.013 & 1.58 & 1.95 & 1.14 & 0.97 \\
\hline & $n$ & 5.24 & 26.31 & 4.88 & 2.12 & 3.72 \\
\hline & $1 / n$ & 0.191 & 0.038 & 0.205 & 0.472 & 0.269 \\
\hline & $R^{2}$ & 0.956 & 0.944 & 0.995 & 0.983 & 0.983 \\
\hline \multirow[t]{3}{*}{ Temkin isotherm } & $K_{\mathrm{T}}\left(\mathrm{L} \mathrm{g} \mathrm{g}^{-1}\right)$ & 24.89 & 32.41 & 27.70 & 1.14 & 4.29 \\
\hline & $b\left(\mathrm{~kJ} \mathrm{~mol}^{-1}\right)$ & 4.28 & 37.43 & 4.34 & 1.72 & 5.04 \\
\hline & $R^{2}$ & 0.954 & 0.944 & 0.993 & 0.991 & 0.975 \\
\hline \multirow[t]{8}{*}{$\mathrm{D}-\mathrm{R}$ isotherm } & $K_{\mathrm{D}-\mathrm{R}}\left(\mathrm{mol}^{2} \mathrm{~kJ}^{-2}\right)$ & 0.826 & 0.11 & -0.95 & 2.91 & 1.93 \\
\hline & & 0.052 & & 0.15 & & \\
\hline & $q_{\mathrm{m}, \mathrm{cal}}\left(\mathrm{mg} \mathrm{g}^{-1}\right)$ & 3.33 & 1.72 & 3.37 & 4.16 & 2.06 \\
\hline & & 2.63 & & 2.68 & & \\
\hline & $E\left(\mathrm{~kJ} \mathrm{~mol}^{-1}\right)$ & 0.78 & 2.15 & - & 0.42 & 0.51 \\
\hline & & 3.10 & & 1.81 & & \\
\hline & $R^{2}$ & 0.887 & 0.946 & 0.931 & 0.908 & 0.894 \\
\hline & & 0.999 & & 0.998 & & \\
\hline
\end{tabular}

Fig. 8 a Langmuir and b D-R isotherms for adsorption of $\mathrm{Cu}^{2+}$ (filled diamond) and $\mathrm{Pb}^{2+}$ (filled square) ions onto $\mathrm{MNS}_{1}$
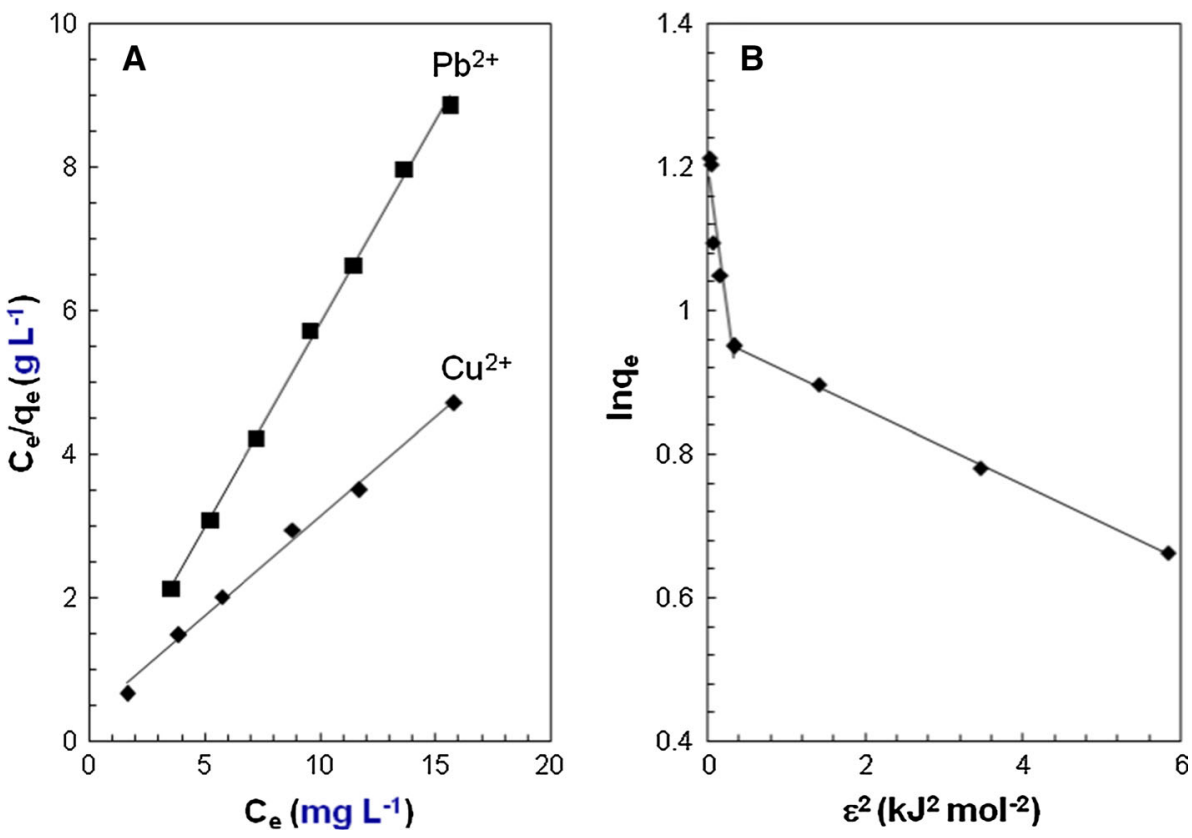

(1930) developed a model (BO model) based on the Langmuir equation. In these equations, it is assumed that each component adsorbs onto the surface according to ideal solute behavior under homogeneous conditions with no interaction or competition between molecules taking place.
It is widely used to calculate the Langmuir constant $Q_{\mathrm{m}}$ in multi-component systems. The common form for depicting the adsorbate distribution is to correlate the amount of solute adsorbed per unit weight of adsorbent with the residual solute concentration remaining in an equilibrium 
Fig. 9 a Langmuir;

b Freundlich; c Temkin; and

d D-R isotherms for adsorption of $\mathrm{Cu}^{2+}$ ions onto $\mathrm{MNS}_{2}$
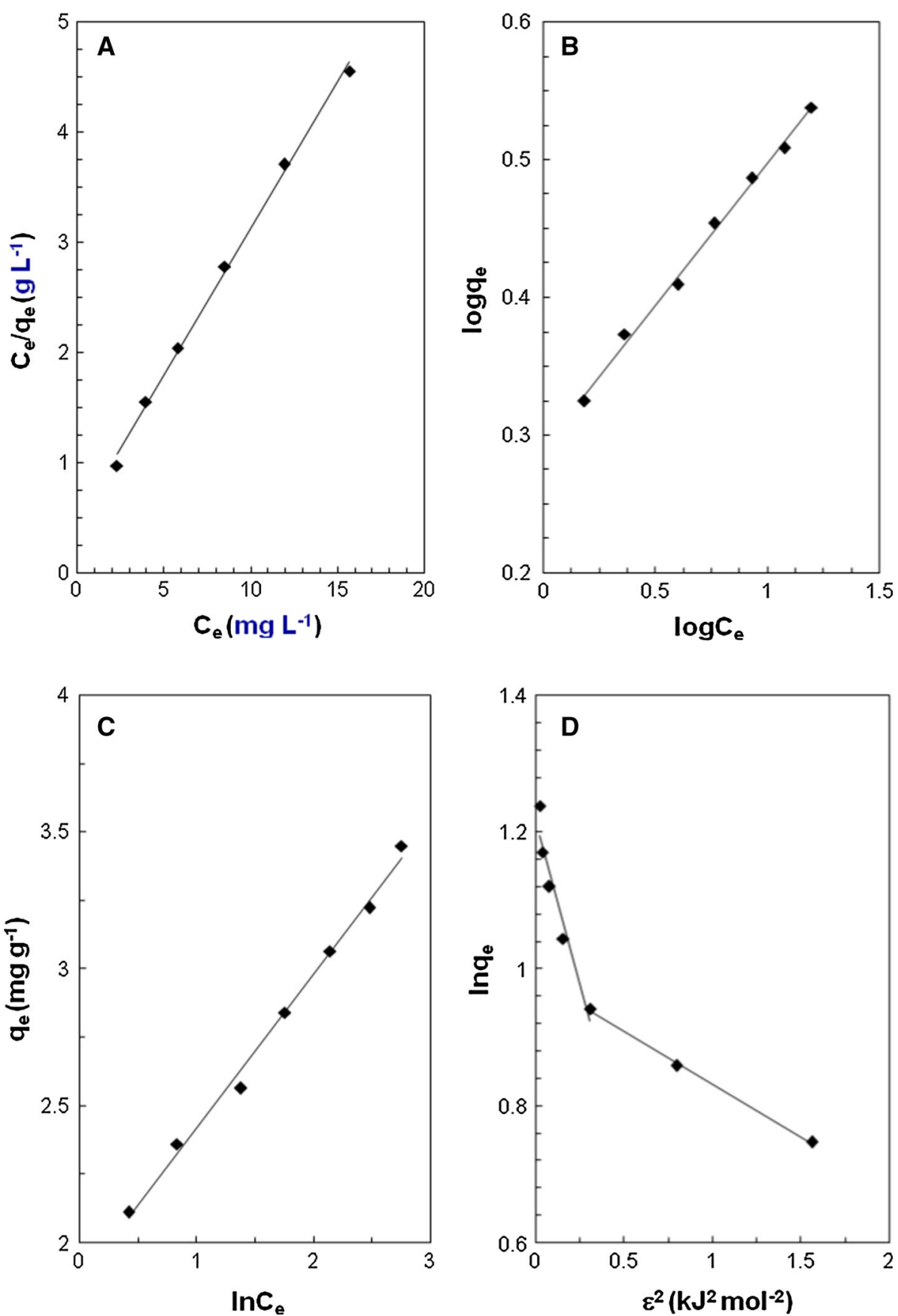

state. If there are two solutes present together in the adsorption system, the extended Langmuir isotherms are (Butler and Ockrent 1930):

$Q_{1}=\frac{q_{\mathrm{m}, 1} K_{\mathrm{L}, 1} C_{\mathrm{e}, 1}}{1+K_{\mathrm{L}, 1} C_{\mathrm{e}, 1}+K_{\mathrm{L}, 2} C_{\mathrm{e}, 2}}$

$Q_{2}=\frac{q_{\mathrm{m}, 2} K_{\mathrm{L}, 2} C_{\mathrm{e}, 2}}{1+K_{\mathrm{L}, 1} C_{\mathrm{e}, 1}+K_{\mathrm{L}, 2} C_{\mathrm{e}, 2}}$

where $Q_{1}$ and $Q_{2}$ are the amounts of solutes 1 and 2 adsorbed per unit weight of adsorbent at equilibrium concentrations $C_{\mathrm{e}, 1}$ and $C_{\mathrm{e}, 2}$, respectively. $q_{\mathrm{m}, 1}$ and $q_{\mathrm{m}, 2}$ are the maximum adsorption capacities of solutes 1 and 2, respectively. These are determined from single-component systems and, therefore, correspond to monolayer coverage of the adsorbent. The parameters $K_{\mathrm{L}, 1}$ and $K_{\mathrm{L}, 2}$ are the Langmuir constants and are a function of the energy of adsorption of solutes 1 and 2, respectively, which are also determined from single-component systems.

The original competitive Langmuir model was improved by Jain and Snoeyink (1973). According to Jain and Snoeyink (JS) model, the Langmuir theory for binary adsorbate systems is based on adsorption without 
Fig. 10 a Langmuir and b Temkin isotherms for adsorption of $\mathrm{Cu}^{2+}$ (filled diamond) and $\mathrm{Pb}^{2+}$ (filled square) ions onto $\mathrm{MNS}_{3}$
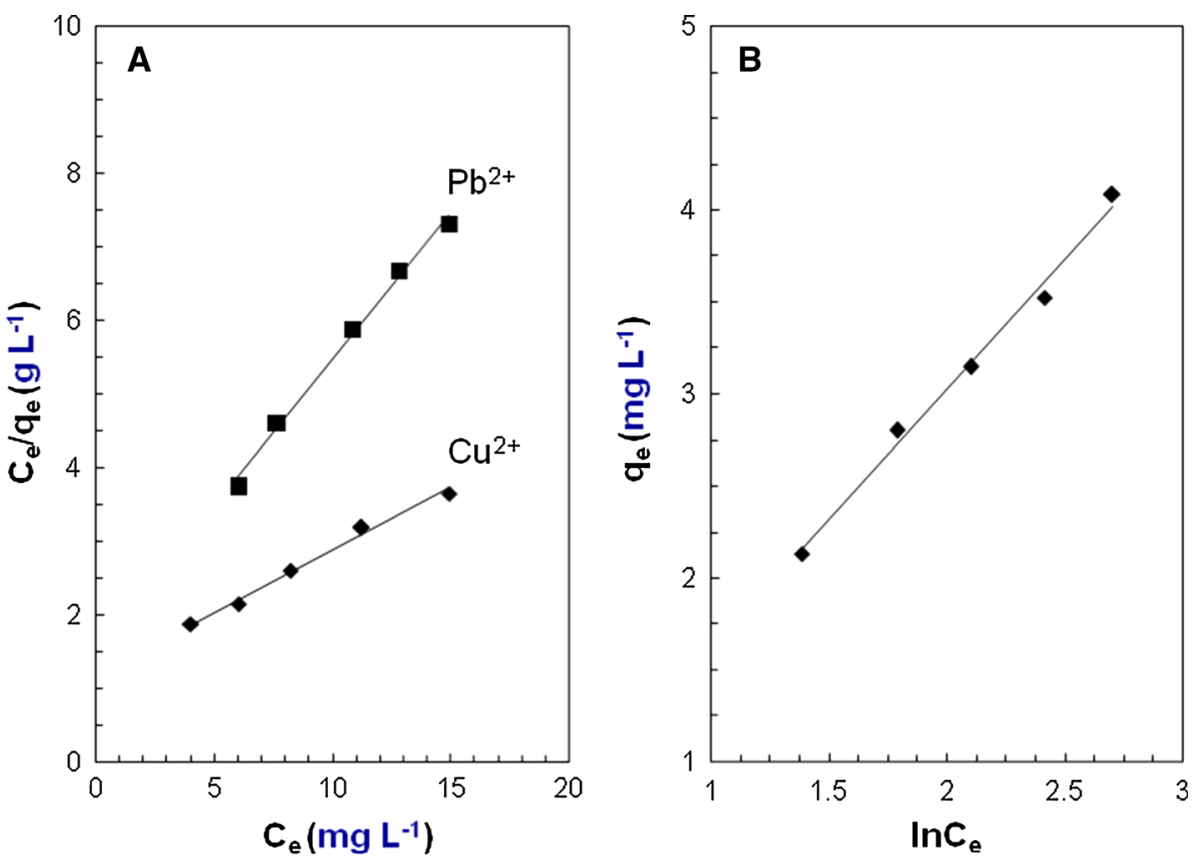

Table 5 Comparison of the proposed method with some of the methods reported in the literature

\begin{tabular}{|c|c|c|c|c|}
\hline Adsorbent & Ion & Adsorption capacity $\left(\mathrm{mg} \mathrm{g}^{-1}\right)$ & Time (min) & References \\
\hline \multirow[t]{2}{*}{$\mathrm{SiO}_{2}-\mathrm{DMABD}^{\mathrm{a}}$} & $\mathrm{Cu}^{2+}$ & 18.6 & 20 & \multirow[t]{2}{*}{ Cui et al. (2006) } \\
\hline & $\mathrm{Pb}^{2+}$ & 6 & 20 & \\
\hline \multirow[t]{2}{*}{ SDS-PVC-BHABDI ${ }^{\mathrm{b}}$} & $\mathrm{Cu}^{2+}$ & 2.6 & 60 & \multirow[t]{2}{*}{ Marahel et al. (2009) } \\
\hline & $\mathrm{Pb}^{2+}$ & 2.2 & 60 & \\
\hline $\mathrm{Fe}_{3} \mathrm{O}_{4} @ \mathrm{SiO}_{2}-\mathrm{Pr}-\mathrm{N}=$ salicylaldehyde & $\mathrm{Cu}^{2+}$ & 97.2 & 60 & Moradinasab and Behzad (2014) \\
\hline \multirow[t]{2}{*}{$\mathrm{MNS}_{1}$} & $\mathrm{Cu}^{2+}$ & 3.73 & 10 & \multirow[t]{2}{*}{ Present work } \\
\hline & $\mathrm{Pb}^{2+}$ & 1.69 & 10 & \\
\hline $\mathrm{MNS}_{2}$ & $\mathrm{Cu}^{2+}$ & 4.12 & 20 & Present work \\
\hline \multirow[t]{2}{*}{$\mathrm{MNS}_{3}$} & $\mathrm{Cu}^{2+}$ & 5.92 & 50 & \multirow[t]{2}{*}{ Present work } \\
\hline & $\mathrm{Pb}^{2+}$ & 5.82 & 50 & \\
\hline
\end{tabular}

${ }^{a}$ p-Dimethylaminobenzaldehyde-modified nanometer $\mathrm{SiO}_{2}$

b Sodium dodecyl sulfate-coated poly(vinyl)chloride modified with bis(2-hydroxyacetophenone)-1,4-butanediimine

competition. Thus, in order to account for competition in the Langmuir theory, the JS model is proposed as (Jain and Snoeyink 1973):

$Q_{1}=\frac{\left(q_{\mathrm{m}, 1}-q_{\mathrm{m}, 2}\right) K_{\mathrm{L}, 1} C_{\mathrm{e}, 1}}{1+K_{\mathrm{L}, 1} C_{\mathrm{e}, 1}}+\frac{q_{\mathrm{m}, 2} K_{\mathrm{L}, 1} C_{\mathrm{e}, 1}}{1+K_{\mathrm{L}, 1} C_{\mathrm{e}, 1}+K_{\mathrm{L}, 2} C_{\mathrm{e}, 2}}$

The first term of Eq. 16 is the Langmuir expression for the number of molecules of solute 1 that are adsorbed without competition on the surface area and is proportional to $\left(q_{\mathrm{m}, 1}-q_{\mathrm{m}, 2}\right)$. It is noteworthy that $q_{\mathrm{m}, 1}>q_{\mathrm{m}, 2}$. The second term in Eq. 16 represents the number of molecules of solute 1 adsorbed on the surface area proportional to $q_{\mathrm{m}, 2}$ in competition with solute 2 . The number of molecules of solute 2 adsorbed on the adsorbent surface is proportional to $q_{\mathrm{m}, 2}$ in competition with solute 1 and can be calculated from Eq. 15.

To predict the results of a multi-component adsorption system, the competitive Langmuir model (BO) and its modified model (JS) were both applied to $\mathrm{Cu}^{2+}$ and $\mathrm{Pb}^{2+}$ ions bisolute system. The obtained data for the adsorption studies are presented in Fig. 11. The low values of adsorbed copper ions predicted by BO model prohibited considering this model for extension of single-component experimental results to the competitive adsorption of copper in the presence of lead ions. This result is not surprising because the competitive Langmuir model is thermodynamically consistent only in the special case where the capacities of the adsorbates are equal. Therefore, it seems 
Fig. 11 Prediction of the competitive removal of $\mathrm{Cu}^{2+}$ and $\mathrm{Pb}^{2+}$ ions based on the $\mathrm{BO}$ and JS models onto $\mathrm{MNS}_{1}$ and $\mathrm{MNS}_{3}$. Filled diamond Singlecomponent system, filled square $\mathrm{BO}$ prediction, filled rectangle JS prediction
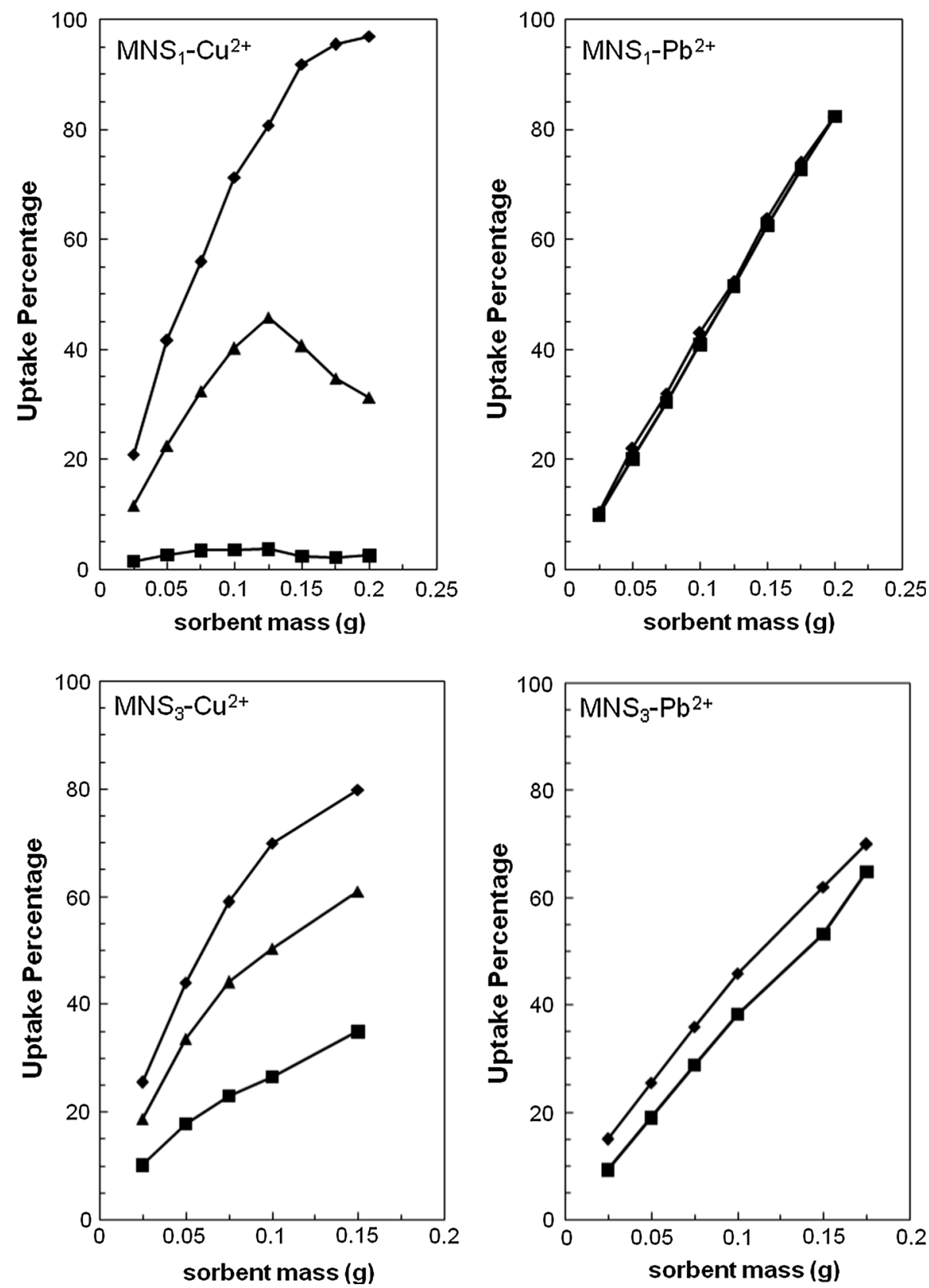

that the predicted values estimated by JS model are more close to that can be obtained experimentally.

However, JS model predicts that although the competition of copper and lead ions adsorption on $\mathrm{MNS}_{3}$ was not altered by adsorbent dose, it is seen that an inverse selectivity in favor of lead ions can be predicted beyond $0.125 \mathrm{~g}$ of the adsorbent $\mathrm{MNS}_{1}$.

\section{Kinetics of adsorption}

Pseudo-first-order, pseudo-second-order, simple Elovich and intra-particle diffusion kinetic models are conventional models examined to investigate the kinetics of adsorption processes (Nameni et al. 2008; Mohaptra et al. 2009). The pseudo-first-order kinetics model assumes that adsorption is controlled by the diffusion step and its adsorption is proportional to the difference in adsorption capacity at equilibrium and at any time $t$ ( $q_{\mathrm{e}}$ and $q_{\mathrm{t}}$, respectively, in $\mathrm{mg} \mathrm{g}^{-1}$ ). This model is mathematically described by Eq. 17:

$\log \left(q_{\mathrm{e}}-q_{\mathrm{t}}\right)=\log q_{\mathrm{e}}-\frac{k_{1, \mathrm{ads}}}{2.303} t$

where $k_{1, \text { ads }}$ is the pseudo-first-order rate constant. 
The pseudo-second-order model describes the relation between the mass of adsorbate per unit mass of adsorbent versus time (Eq. 18):

$\frac{t}{q_{\mathrm{t}}}=\frac{1}{k_{2, \mathrm{ads}} q_{\mathrm{e}}^{2}}+\frac{t}{q_{\mathrm{e}}}$

where $k_{2 \text {,ads }}$ denotes the pseudo-second-order rate constant. In this model, the initial rate of adsorption is when $q_{t} / t$ approaches zero. This means that:

$h_{0}=k_{2} q_{\mathrm{e}}^{2}$

where $h_{0}$ is the initial rate of adsorption $\left(\mathrm{mg} \mathrm{g}^{-1} \mathrm{~min}^{-1}\right)$.

The Elovich equation establishes if the process is controlled by diffusion or chemical reaction. In this model, the adsorption kinetics for a homogeneous surface is mathematically shown in Eq. 20 as:

$q_{\mathrm{t}}=a+2.303 b \log t$

where $a$ is the desorption constant $\left(\mathrm{mg} \mathrm{g}^{-1}\right)$ and is a function of both particle structural-chemical characteristics and the solute diffusion coefficient, and $b$ is the initial adsorption rate $\left(\mathrm{mg} \mathrm{g}^{-1} \mathrm{~min}^{-1}\right)$. These quantities can be obtained from plots of $q_{\mathrm{t}}$ versus $\log t$.

Intra-particle diffusion in the solid phase is the ratecontrolling step, and the mathematical equation describing adsorption is the Weber and Morris equation (Ho 2006) (Eq. 21):

$q_{\mathrm{t}}=k_{\text {int }} \sqrt{t}+C$

where $k_{\text {int }}$ is the intra-particle diffusion equation constant ( $\mathrm{mg} \mathrm{g}^{-1} \min ^{-0.5}$ ) and $C$ is a constant. In this model, the plot of $q_{t}$ versus $t^{0.5}$ should be a straight line when diffusion influences the adsorption rate and should cross the origin if intra-particle diffusion is the rate-determining step.

Table 6 lists the kinetic parameters for the models on the adsorption of copper and lead ions onto $\mathrm{MNS}_{1}, \mathrm{MNS}_{2}$ and $\mathrm{MNS}_{3}$. The pseudo-second-order kinetic model provided an impressive and comparable correlation for the adsorption of ions. Although $R^{2}$ for the pseudo-first-order model for metal adsorption was similar to that for the pseudo-second-order kinetic model, $q_{\mathrm{e}}$ values for the former model were very different from those experimentally determined $\left(q_{\text {exp }}\right)$. It suggests that the rate-determining step for adsorption is chemical adsorption and that adsorption involves valence forces from sharing of electrons by the metal ions and adsorbents ( $\mathrm{Yu}$ et al. 2012; Bhattacharya et al. 2008; Zhou et al. 2011). $\mathrm{MNS}_{1}, \mathrm{MNS}_{2}$ and $\mathrm{MNS}_{3}$ have chelating functional groups on their surfaces that probably behave as chelating exchangers; therefore, a complexation reaction is expected for adsorption (Zhou et al. 2009).
Table 6 Parameters evaluated by using different kinetic models for interpreting the experimental data of the adsorption of copper and lead ions onto the studied adsorbents

\begin{tabular}{|c|c|c|c|c|c|c|}
\hline \multirow[t]{2}{*}{ Kinetic models } & \multirow[t]{2}{*}{ Parameter } & \multicolumn{2}{|l|}{$\mathrm{MNS}_{1}$} & \multirow{2}{*}{$\begin{array}{l}\mathrm{MNS}_{2} \\
\mathrm{Cu}^{2+}\end{array}$} & \multicolumn{2}{|l|}{$\mathrm{MNS}_{3}$} \\
\hline & & $\mathrm{Cu}^{2+}$ & $\mathrm{Pb}^{2+}$ & & $\mathrm{Cu}^{2+}$ & $\mathrm{Pb}^{2+}$ \\
\hline \multirow[t]{4}{*}{ Pseudo-first-order equation } & $q_{\mathrm{e}, \exp }\left(\mathrm{mg} \mathrm{g}^{-1}\right)$ & 2.75 & 1.8 & 2.90 & 2.80 & 1.64 \\
\hline & $q_{\mathrm{e}, \mathrm{cal}}\left(\mathrm{mg} \mathrm{g}^{-1}\right)$ & 0.39 & 0.59 & 2.43 & 1.22 & 2.05 \\
\hline & $k_{1}\left(\min ^{-1}\right)$ & 0.25 & 0.20 & 0.15 & 0.06 & 0.06 \\
\hline & $R^{2}$ & 0.995 & 0.997 & 0.898 & 0.994 & 0.981 \\
\hline \multirow[t]{4}{*}{ Pseudo-second-order equation } & $q_{\mathrm{e}, \mathrm{cal}}\left(\mathrm{mg} \mathrm{g}^{-1}\right)$ & 2.79 & 1.91 & 3.27 & 2.89 & 2.22 \\
\hline & $k_{2}\left(\mathrm{~g} \mathrm{mg}^{-1} \min ^{-1}\right)$ & 1.27 & 0.54 & 0.08 & 0.11 & 0.02 \\
\hline & $h\left(\mathrm{mg} \mathrm{g}^{-1} \min ^{-1}\right)$ & 9.90 & 1.99 & 0.85 & 0.94 & 0.09 \\
\hline & $R^{2}$ & 1.000 & 0.999 & 0.995 & 0.999 & 0.992 \\
\hline \multirow[t]{6}{*}{ Elovich equation } & $a\left(\mathrm{mg} \mathrm{g}^{-1}\right)$ & 2.44 & 1.25 & 0.92 & $1.34^{\mathrm{a}}$ & -0.54 \\
\hline & & & & & $2.50^{\mathrm{b}}$ & \\
\hline & $b\left(\mathrm{mg} \mathrm{g}^{-1} \min ^{-1}\right)$ & 0.11 & 0.20 & 0.59 & $0.36^{\mathrm{a}}$ & 0.51 \\
\hline & & & & & $0.06^{\mathrm{b}}$ & \\
\hline & $R^{2}$ & 0.930 & 0.996 & 0.982 & $0.981^{\mathrm{a}}$ & 0.992 \\
\hline & & & & & $0.92^{\mathrm{b}}$ & \\
\hline \multirow[t]{6}{*}{ Intra-particle diffusion equation } & $k_{3}\left(\mathrm{mg} \mathrm{g}^{-1} \min ^{-1 / 2}\right)$ & 0.074 & 0.15 & 0.364 & $0.23^{\mathrm{a}}$ & 0.25 \\
\hline & & & & & $0.04^{\mathrm{b}}$ & \\
\hline & $\mathrm{C}$ & 2.45 & 1.23 & 1.04 & $1.36^{\mathrm{a}}$ & -0.25 \\
\hline & & & & & $2.45^{\mathrm{b}}$ & \\
\hline & $R^{2}$ & 0.856 & 0.975 & 0.965 & $0.993^{\mathrm{a}}$ & 0.973 \\
\hline & & & & & $0.915^{\mathrm{b}}$ & \\
\hline
\end{tabular}

a Parameters determined based on the first linear range of the studied model

b Parameters determined based on the second linear range of the studied model 


\section{Conclusion}

Nanosilica particles modified with Schiff base ligands 3-methoxy salicylaldimine propyl triethoxysilane $\left(\mathrm{MNS}_{1}\right)$, 5-bromo salicylaldimine propyl triethoxysilane $\left(\mathrm{MNS}_{2}\right)$ and 3-hydroxy salicylaldimine propyl triethoxysilane $\left(\mathrm{MNS}_{3}\right)$ are potential adsorbents for selective removal of copper and lead ions from aqueous solutions. $\mathrm{MNS}_{2}$ demonstrated excellent selectivity for removal of copper ions. Although the efficiency of $\mathrm{MNS}_{3}$ for removal of $\mathrm{Zn}^{2+}, \mathrm{Cd}^{2+}, \mathrm{Co}^{2+}$ and $\mathrm{Ni}^{2+}$ ions was shown, more investigation is required to optimize the experimental conditions for quantitative removal of these ions from aqueous solutions.

Adsorption-desorption of the metal ions onto the adsorbents allow their use repeatedly for removal of copper and lead ions from aqueous solutions. Evaluated thermodynamic parameters indicated that the adsorption processes were endothermic and controlled by entropy changes. The isotherms describing the experimental results of adsorption depend on the metal ions and type of adsorbent. The adsorption kinetics were described by considering pseudosecond-order reaction with chemisorption as the rate-limiting mechanism. The Elovich equation indicates both the chemisorption nature of adsorption and the heterogeneous surface of adsorbent.

Acknowledgments The authors would like to thank the University of Zanjan for their financial support (Grant Number EA/7774 21-112013) of this study.

\section{References}

Agrawal SK (2009) Heavy metal pollution. A. P. H. Publishing Corporation, New Delhi

Bhattacharya AK, Naiya TK, Mondal SN, Das SK (2008) Adsorption, kinetics and equilibrium studies on removal of $\mathrm{Cr}(\mathrm{VI})$ from aqueous solutions using different low-cost sorbents. Chem Eng J 137:529-541

Butler JAV, Ockrent C (1930) Studies in electrocapillarity. Part III. The surface tensions of solutions containing two surface-active solutes. J Phys Chem 34:2841-2859

Cui Y, Chang X, Zhai Y, Zhu X, Zheng H, Lian N (2006) ICP-AES determination of trace elements after preconcentrated with p-dimethylaminobenzaldehyde-modified nanometer $\mathrm{SiO}_{2}$ from sample solution. Microchem J 83:35-41

Dabrowski A, Podkoscielny P, Hubicki Z, Barczak M (2005) Adsorption of phenolic compounds by activated carbon: a critical review. Chemosphere 58:1049-1070

Dean JA (1995) Analytical chemistry handbook. McGraw-Hill, New York

Fathi SAM, Yaftian MR (2009) Cloud point extraction and flame atomic absorption spectrometry determination of trace amounts of copper(II) ions in water samples. J Colloid Interface Sci 334:167-170

Fathi SAM, Parinejad M, Yaftian MR (2008) Multidentate nitrogen/ oxygen donor ionophores; their use as selective extracting and mobile-carrier agents for copper(II) ions. Sep Purif Technol 64:1-7

Fathi SAM, Rostamkhani S, Yaftian MR (2010) Determination of trace amounts of copper in water samples by flame atomic absorption spectrometry after preconcentration on octadecylbonded silica membranes modified by a di-Schiff base ligand. J Anal Chem 65:614-619

Fu F, Wang Q (2011) Removal of heavy metal ions from wastewaters: a review. J Environ Manag 92:407-418

Ghasemi Z, Seif A, Ahmadi TS, Zargar B, Rashidi F, Rouzbahani GM (2012) Thermodynamic and kinetic studies for the adsorption of $\mathrm{Hg}$ (II) by nano- $\mathrm{TiO}_{2}$ from aqueous solution. Adv Powder Technol 23:148-156

Ghorbanloo M, Monfared HH, Janiak C (2011) The catalytic function of a silica gel-immobilized $\mathrm{Mn}$ (II)-hydrazide complex for alkene epoxidation with $\mathrm{H}_{2} \mathrm{O}_{2}$. J Mol Catal A: Chem 345:12-20

Ho YS (2006) Isotherm for the sorption of lead onto peat: comparison of linear and non-linear methods. Pol J Environ Stud 15:81-86

Ho YS, McKay G (2000) Correlative biosorption equilibria model for a binary batch system. Chem Eng Sci 55:817-825

Hoque ME, Philip OJ (2011) Biotechnological recovery of heavy metals from secondary sources: an overview. Mater Sci Eng 31:57-66

Jain JS, Snoeyink VL (1973) Adsorption from bisolute systems on active carbon. J Water Pollut Control Fed 45:2463-2479

Janschm M, Stumf P, Graf C, Rühi E, Müller RH (2012) Adsorption kinetics of plasma proteins on ultrasmall superparamagnetic iron oxide (USPIO) nanoparticles. Int J Pharm 428:125-133

Jiang Y, Pang H, Liao B (2009) Removal of copper(II) ions from aqueous solution by modified bagasse. J Hazard Mater 164:1-9

Lin S, Juang R (2002) Heavy metal removal from water by sorption using surfactant modified montmorillonite. J Hazard Mater 92:315-326

Liu Y, Chen M, Hao Y (2013) Study on the adsorption of $\mathrm{Cu}(\mathrm{II})$ by EDTA functionalized $\mathrm{Fe}_{3} \mathrm{O}_{4}$ magnetic nano-particles. Chem Eng J 218:46-54

Marahel F, Ghaedi M, Shokrollahi A, Montazerzohori M, Davoodi S (2009) Sodium dodecyl sulfate coated poly(vinyl) chloride: an alternative support for solid phase extraction of some transition and heavy metals. Chemosphere 74:583-589

Mohaptra M, Khatun S, Andad S (2009) Adsorption behavior of $\mathrm{Pb}(\mathrm{II}), \mathrm{Cd}(\mathrm{II})$ and $\mathrm{Zn}(\mathrm{II})$ on NALCO plant sand. Indian J Chem Technol 16:291-300

Moradinasab S, Behzad M (2014) Removal of heavy metals from aqueous solution using $\mathrm{Fe}_{3} \mathrm{O}_{4}$ nanoparticles coated with Schiff base ligand. Desalin Water Treat 52:1-9

Nameni M, Alavi Moghadam MR, Arami M (2008) Adsorption of hexavalent chromium from aqueous solutions by wheat bran. Int J Environ Sci Technol 5:161-168

Önnby L, Svensson C, Mbundi L, Busquets R, Cundy A, Kirsebom H (2014) $\gamma-\mathrm{Al}_{2} \mathrm{O}_{3}$-based nanocomposite adsorbents for arsenic $(\mathrm{V})$ removal: assessing performance, toxicity and particle leakage. Sci Total Environ 473-474:207-214

Oshima S, Hirayama N, Kubono K, Kokusen H, Honjo T (2003) Ionpair extraction behavior of divalent metal cations using neutral di-Schiff base ligands derived from 1,2-cyclohexanediamine and o-phenylenediamine. Talanta 59:867-874

Ozcan A, Oncu EM, Ozcan AS (2006) Kinetics, isotherm and thermodynamic studies of adsorption of acid blue 193 from aqueous solutions onto natural sepiolite. Colloid Surf A 277:90-97

Pilehvari Z, Yaftian MR, Rayati S, Parinejad M (2007) A novel wiretype lead-selective electrode based on bis(1'-hydroxy-2'-acetonaphthone)-2,2'-diiminodiethylamine. Ann Chim 97:747-757

Shamsipur M, Ghiasvand AR, Sharghi H, Naeimi H (2000) Solid phase extraction of ultra trace copper(II) using octadecyl silica 
membrane disks modified by a naphthol-derivative Schiff's base. Anal Chim Acta 408:271-277

Shemirani F, Jamali MR, Kozani RR, Salavati-Niasari M (2006) Cloud point extraction and preconcentration for the determination of $\mathrm{Cu}$ and $\mathrm{Ni}$ in natural water by flame atomic absorption spectrometry. Sep Sci Technol 41:3065-3077

Shiri-Yekta Z, Yaftian MR, Nilchi A (2013) Silica nanoparticles modified with a Schiff base ligand: an efficient adsorbent for Th(IV), U(VI) and Eu(III) ions. Korean J Chem Eng 30:1644-1651

Shokrolahi A, Ghaedi M, Ghaedi H (2007) Potentiometric and spectrophotometric studies of copper(II) complexes of some ligands in aqueous and nonaqueous solution. J Chin Chem Soc 54:933-940

Tu YJ, You CF, Chang CK (2012) Kinetics and thermodynamics of adsorption for $\mathrm{Cd}$ on green manufactured nano-particles. J Hazard Mater 235-236:116-122

Wurster DE, Alkhamis KA, Matheson LE (2000) Prediction of Adsorption from multicomponent solutions by activated carbon using single-solute parameters. AAPS Pharm Sci Tech 1(3): article 25
Yu JX, Chi RA, Zhang YF, Xu ZG, Xiao CQ, Guo J (2012) A situ coprecipitation method to prepare magnetic PMDA modified sugarcane bagasse and its application for competitive adsorption of methylene blue and basic magenta. Bioresour Technol 110:160-166

Yu J-G, Zhao X-H, Yang H, Chen X-H, Yang Q, Yu L-Y, Jiang J-H, Chen X-Q (2014) Aqueous adsorption and removal of organic contaminants by carbon nanotubes. Sci Total Environ 482-483:241-251

Zhang X, Jiao C, Wang J, Liu Q, Li R, Yang P, Zhang M (2012) Removal of uranium(VI) from aqueous solutions by magnetic Schiff base: kinetic and thermodynamic investigation. Chem Eng J 198-199:412-419

Zhou YT, Christopher BW, Nie HL (2009) Adsorption mechanism of $\mathrm{Cu}^{2+}$ from aqueous solution by chitosan-coated magnetic nanoparticles modified with $\alpha$-ketoglutaric acid. Colloid Surf B $74: 244-252$

Zhou LM, Jin JY, Liu ZR, Liang XZ, Shang C (2011) Adsorption of acid dyes from aqueous solutions by the ethylenediaminemodified magnetic chitosan nanoparticles. J Hazard Mater 185:1045-1052 